\title{
24. TECTONICS OF THE CENTRAL NEW HEBRIDES ARC, NORTH AOBA BASIN ${ }^{1}$
}

\author{
Bernard Pelletier, ${ }^{2}$ Martin Meschede, ${ }^{3}$ Thierry Chabernaud, ${ }^{4}$ Pierrick Roperch, ${ }^{5}$ and Xixi Zhao ${ }^{6}$
}

\begin{abstract}
Drilling at Sites 832 and 833 in the North Aoba Basin provided the first continuous section in the central New Hebrides Island Arc from the Late Miocene. We report here tectonic structures observed in the cores and data obtained from the boreholes with the Formation MicroScanner logging tool. The structures observed on cores were geographically oriented using the declination of the natural remanent magnetism obtained from continuous core sections and from discrete samples. The corrected data are generally in good agreement with in-situ Formation MicroScanner measurements, indicating the reliability of the reorientation method that assumes that no tectonic rotation occurred since the deposition of the sediments. Finally, structural data allow us to obtain information concerning the deformations, especially the direction of sequence tilting and the orientations of principal stress axes. Using also the lithostratigraphy, we reconstruct the late Miocene to Pleistocene tectonic history recorded in the North Aoba Basin and attempt to correlate these data with the onshore geology in the context of the New Hebrides Island Arc-d'Entrecasteaux Zone collision.
\end{abstract}

\section{INTRODUCTION}

In the southwest Pacific, the New Hebrides Island Arc extends over $1700 \mathrm{~km}$ delineating a major converging plate boundary along which the Australian plate is subducting to the east beneath the Pacific plate and the North Fiji Basin. The morphology and the structure of the central part of the arc, between $14^{\circ} 30^{\prime} \mathrm{S}$ and $17^{\circ} 00^{\prime} \mathrm{S}$, are strongly perturbed by the subduction of the d'Entrecasteaux Zone (Fig. 1). East of the d'Entrecasteaux Zone, the arc is characterized by the absence of the physiographic trench (Daniel and Katz, 1981; Collot et al., 1985), the presence of large islands arranged into three parallel island chains (Western Belt, Central Chain, and Eastern Belt: Mitchell and Warden, 1971), and the unusual presence of the deep-water Aoba Basin (2000-3000 m) in the middle of the summit platform of the arc. The Aoba Basin is bounded on the west and east by the Western (Malakula and Espiritu Santo islands) and the Eastern (Pentecost and Maewo islands) Belts, and is divided along strike into the North and South Aoba Basins by the active Aoba volcano of the Central Chain. The deep-water Aoba Basin is also bounded to the north and south by a relatively shallow-water arc platform complex composed of platform basins and active volcanoes of the Central Chain.

During Leg 134, Sites 832 and 833 (Figs. 1 and 2) were drilled in the North Aoba Basin to investigate the influence of the d'Entrecasteaux Zone subduction-collision on the development of the interarc basin and the evolution of the magmatic arc (Collot, Greene, Stokking, et al., 1992). Previous geological and geophysical studies of the North and South Aoba Basins were described by Luyendyk et al. (1974), Ravenne et al. (1977), Carney and Macfarlane (1980, 1982), Katz (1981, 1988), Pontoise (1984), Collot and Fisher (1988), Fisher et al. (1988), Greene and Johnson (1988), Holmes (1988), and Daniel et al. (1989). These studies reported a variety of interpretations of thicknesses and ages of the sequences as well as the number and ages of unconformities observed on seismic reflection profiles. Leg 134 provided the first opportunity to directly determine the nature and the age of the basin fill.

\footnotetext{
${ }^{1}$ Greene, H.G., Collot, J.-Y., Stokking, L.B., et al., 1994. Proc. ODP, Sci. Results, 134: College Station, TX (Ocean Drilling Program).

${ }^{2}$ ORSTOM, BP A5, Nouméa, New Caledonia.

${ }^{3}$ Institut für Geologie, Universität Tübingen, Sigwartstrasse 10, D-7400 Tübingen, Germany.

${ }^{4}$ Borehole Research Group, Lamont-Doherty Earth Observatory, Palisades, NY 10964, U.S.A.

${ }^{5}$ ORSTOM, BP 48, 06230 Villefranche-sur-Mer, France.

${ }^{6}$ Earth Science Board, University of California, Santa Cruz, CA 95064, U.S.A.
}

We report here the type and the depth distribution of the structures observed at Sites 832 and 833 . Orientation of the structures observed in the cores using paleomagnetic data, as well as in-situ Formation MicroScanner (FMS) measurements, provide information concerning deformation, such as directions of sequence tilting and principal stress axes. Finally, using the lithostratigraphy, we reconstruct the late Miocene to Pleistocene tectonic history recorded in the North Aoba Basin and attempt to correlate these data with the onshore geology of the Western and Eastern Belts in the context of the arc-ridge collision.

\section{METHODS}

Special attention was made to identify, measure, and orient structural features observed in the cores at Sites 832 and 833 where recovery rates were relatively good ( $46.9 \%$ for Hole $832 \mathrm{~B}$ from 144 to 1106 mbsf, and $56.2 \%$ for Hole $833 \mathrm{~B}$ from 77 to $1001 \mathrm{mbsf}$ ). The objective was to determine the orientation and the relative magnitudes of the principal stresses. Such a type of study was first conducted during Leg 131 in the Nankai accretionary prism (Taira, Hill, Firth, et al., 1991; Lallemant et al., 1993). For the first time, we assess the reliability of the orientation method using in-situ FMS measurements in Holes 832B and $833 \mathrm{~B}$.

\section{Measurement and Orientation of the Structural Features}

Macroscopic features like bedding, faults, scaly fabrics, veins, and striations observed in the split cores at Sites 832 and 833 were first measured and oriented relative to core reference coordinates (Shipboard Scientific Party, 1992). Deviations of the borehole from vertical were negligible $\left(<5^{\circ}\right)$, and no drift correction was applied. The orientation of the observed features was then corrected to the true geographic coordinates using paleomagnetic measurements obtained on the core using a pass-through cryogenic magnetometer and on discrete samples taken from the core. The declination of the natural remanent magnetism was used to estimate and remove drilling-induced rotations of the cores. The use of the primary magnetization to reorient the observed structures assumes that the paleomagnetic field does not differ from the present day geographic axis, and thus no tectonic rotation occurred since the deposition of the sediments. Comparison of the FMS data with the AMS (anisotropy of magnetic susceptibility) data at Site 833 confirms this assumption and indicates that no rotation of the New Hebrides Island Arc occurred since the middle Pliocene (Roperch et al., this volume). About 300 plane structures have been measured in the cores from Hole 832B and 570 from Hole 833B. Azimuth corrections have been applied to $80 \%$ and $71 \%$ of these 


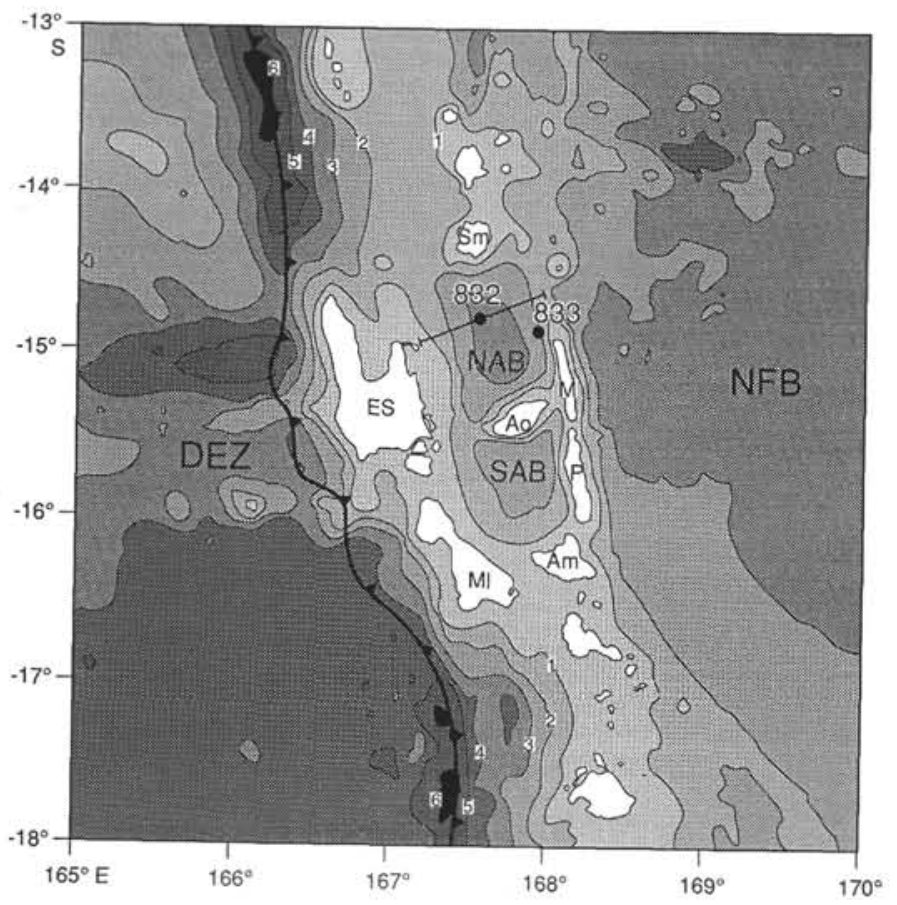

Figure 1. Bathymetric map of the central New Hebrides Island Arc and location of ODP Sites 832 and 833 in the North Aoba Basin. Bathymetry in kilometers. $\mathrm{DEZ}=$ d'Entrecasteaux Zone; NFB = North Fiji Basin; NAB = North Aoba Basin; $\mathrm{SAB}=$ South Aoba Basin; $\mathrm{ES}=$ Espiritu Santo; $\mathrm{Ml}=$ Malakula; $\mathrm{Am}=$ Ambrym $; \mathrm{Ao}=$ Aoba $; \mathrm{Sm}=$ Santa Maria $; \mathrm{M}=$ Maewo; $\mathrm{P}=$ Pentecost. Thick line with teeth indicates plate boundary. Location of seismic reflection line of Figure 2 is shown.

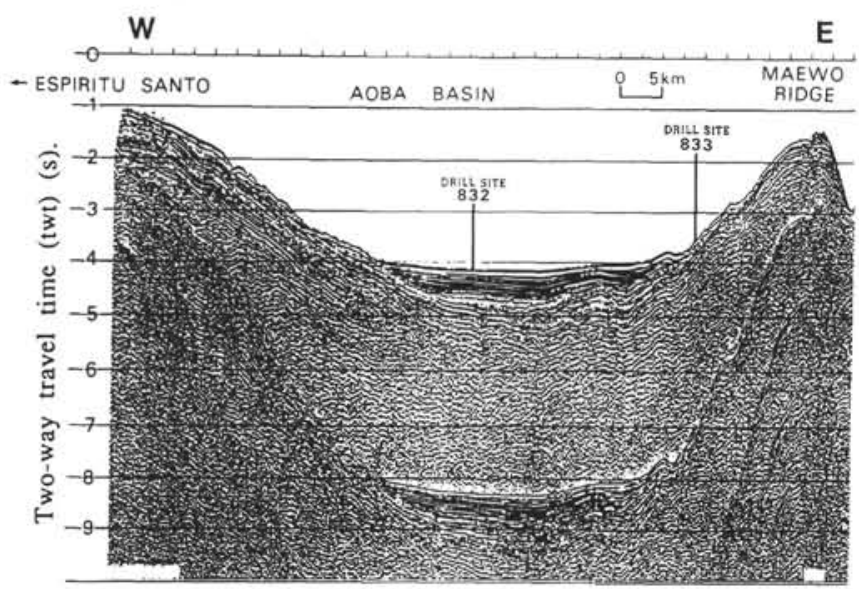

Figure 2. Multichannel seismic reflection profile (Line 19, L5-1982-SP cruise, USGS) showing the overall structure of the North Aoba Basin. The line crosses over Site 832. Location of Site 833 farther to the south is projected on this line.

planes for Holes 832B and 833B, respectively. The decrease in scattering of the trend of slickensides, after correction using paleomagnetic information, illustrates the consistency of the data set and the efficiency of the reorientation method (Fig. 3).

\section{Comparison with the FMS Data}

The reliability of the reoriented measurements can also be checked by comparison with the in-situ FMS measurements. The FMS pro-
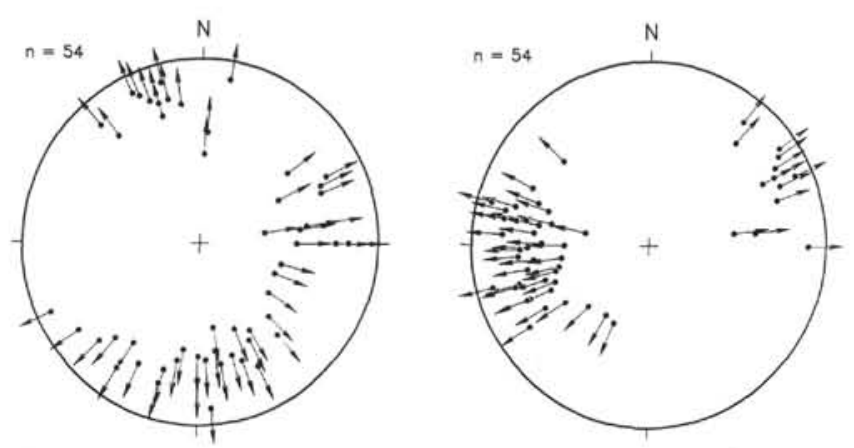

Figure 3. Stereographic plots of slickenside lineations before (left) and after (right) corrections using paleomagnetic data. $n=$ number of samples. Note the decrease in scattering of the slickenside azimuths after reorientation. This example shows slickensides on normal faults observed in Core 134-832B-64R. Equal-area lower hemisphere projection.

Table 1. Comparison of the dip and dip direction of the bedding planes between results from measurements after paleomagnetic corrections and results from Leg 134 FMS logging.

\begin{tabular}{|c|c|c|c|c|c|c|}
\hline Site & Unit & $\begin{array}{c}\text { Type of } \\
\text { data }\end{array}$ & $N$ & DD & $\mathrm{D}$ & 99 \\
\hline 832 & V & Oriented & 19 & 100 & 6 & 5.7 \\
\hline 832 & V & Int. FMS & 203 & 95 & 5 & 1.0 \\
\hline 832 & VI & Int. FMS & 56 & 49 & 12 & 7.0 \\
\hline 833 & I+II & Oriented & 68 & 246 & 9 & 3.6 \\
\hline 833 & III & Oriented & 46 & 218 & 7 & 5.8 \\
\hline 833 & III & Int. FMS & 25 & 217 & 22 & 5.8 \\
\hline 833 & III & Aut. FMS & 358 & 239 & 14 & 1.0 \\
\hline 833 & IV & Oriented & 129 & 261 & 8 & 3.6 \\
\hline 833 & IV & Int. FMS & 93 & 250 & 19 & 5.7 \\
\hline 833 & IVu & Oriented & 100 & 261 & 10 & 2.6 \\
\hline 833 & IVu & Aut. FMS & 1341 & 251 & 13 & 0.5 \\
\hline 833 & IVI & Oriented & 29 & 257 & 3 & 14 \\
\hline 833 & IVI & Aut. FMS & 61 & 261 & 20 & 8.1 \\
\hline 833 & V & Oriented & 14 & 279 & 21 & 5.0 \\
\hline 833 & V & Int. FMS & 41 & 249 & 25 & 5.0 \\
\hline
\end{tabular}

Notes: At Site 833, u = upper $(616-762 \mathrm{mbsf})$ and $\mathrm{l}=$ Jower (762-830 mbsf) parts of lithostratigraphic Unit IV, respectively. Oriented $=$ bedding measured on cores and corrected using paleomagnetic data; Int. FMS = bedding mapped interactively on FMS images; Aut. FMS = bedding automatically computed from FMS data. $N=$ number of samples used to calculate the mean direction. $\mathrm{DD}=$ dip direction of the bedding in degrees. $\mathrm{D}=$ dip of the bedding in degrees. $99=$ angle of confidence at $99 \%$.

duces spatially oriented high-resolution images of the borehole wall that can be used for detailed correlation of coring and logging depths, core orientation, mapping of bedding planes, fractures, faults, foliations, and other formation structures, as well as determining the strikes and dips of planar features. FMS images also can be used to measure stress in the borehole through breakouts (Chabernaud and Krammer, this volume). FMS data were obtained between 630 and $1090 \mathrm{mbsf}$ in Hole 832B and between 557 and $934 \mathrm{mbsf}$ in Hole 833B. Orientations of the bedding planes observed in the cores and corrected by paleomagnetic data generally agree well with those obtained by the FMS data (Table 1). However, FMS and reoriented core data partly differ for fault planes. Because the paleomagnetically oriented azimuths of bedding planes are consistent with the bedding azimuths determined from FMS data, reorientation is inferred to be also reliable for the fault planes. The discrepancy could be due to a difference in sampling between faults imaged by FMS and faults observed in cores. FMS easily records faults produced by drilling and regional stresses in the borehole; such faults that fractured the cores are difficult to identify in the cores. The normal microfaults observed in the cores 
Table 2. Results of the stress tensor inversion of striated faults at Sites 832 and 833 .

\begin{tabular}{|c|c|c|c|c|c|c|}
\hline \multirow[b]{2}{*}{ Hole, core } & \multirow[b]{2}{*}{$N$} & \multicolumn{2}{|c|}{ Sigma 1} & \multicolumn{2}{|c|}{ Sigma 3} & \multirow[b]{2}{*}{$\mathbf{R}$} \\
\hline & & Trend & Plunge & Trend & Plunge & \\
\hline \multicolumn{7}{|l|}{ Normal faults } \\
\hline $832 \mathrm{~B}-63 \mathrm{R}$ & 23 & 319 & 88 & 70 & 1 & 0.99 \\
\hline $832 \mathrm{~B}-64 \mathrm{R}$ & 54 & 251 & 88 & 64 & 2 & 0.96 \\
\hline $832 B-65 R$ & 21 & 255 & 89 & 122 & 1 & 0.98 \\
\hline $832 \mathrm{~B}-63$ to $-65 \mathrm{R}$ & 90 & 284 & 89 & 65 & 1 & 0.98 \\
\hline $832 \mathrm{~B}-69$ to $-74 \mathrm{R}$ & 19 & 295 & 88 & 111 & 2 & 0.99 \\
\hline $833 B-60$ to $-67 R$ & 33 & 228 & 89 & 9 & 0 & 0.91 \\
\hline $833 \mathrm{~B}-73$ to $-74 \mathrm{R}$ & 12 & 85 & 79 & 201 & 5 & 0.86 \\
\hline $833 \mathrm{~B}-75$ to $-78 \mathrm{R}$ & 19 & 183 & 74 & 290 & 5 & 0.92 \\
\hline $833 \mathrm{~B}-80 \mathrm{R}$ & 10 & 105 & 75 & 358 & 5 & 0.69 \\
\hline 833B-93R & 4 & 184 & 75 & 39 & 13 & 0.92 \\
\hline $833 B-60$ to $-93 R$ & 78 & 76 & 86 & 190 & 2 & 0.95 \\
\hline \multicolumn{7}{|c|}{ Strike-slip and reverse faults } \\
\hline 833B & 9 & 51 & 0 & 323 & 81 & 0.94 \\
\hline
\end{tabular}

Notes: $N=$ number of faults used to determine the stress tensor solutions. $\mathrm{R}=$ ratio (sigma 2 - sigma $1 /$ sigma 3 - sigma 1 ).

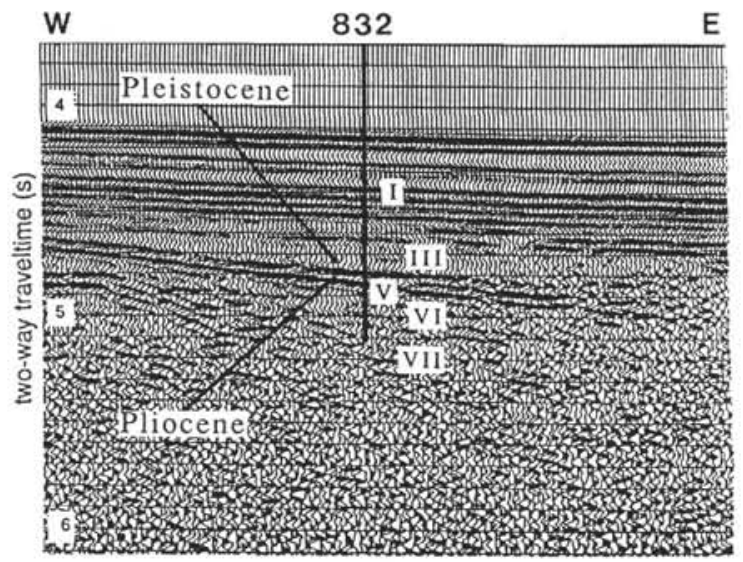

Figure 4. Part of a multichannel seismic reflection profile (Line 1041, Multipso cruise, 1989, ORSTOM) showing the acoustic stratigraphy at Site 832. Roman numerals correspond to lithostratigraphic units of Figure 5.

exhibit only small displacements and probably have no high signature of resistivity and thus are poorly or not discernible in the FMS images.

\section{Determination of the Stress Tensor}

Since the orientation of the fault planes is confidently estimated, the motion along the fault planes enables us to determine the principal stress orientations and the relative magnitude of the principal stresses. Consequently, special attention was focused on striated fault planes. The sense of motion along the faults was deduced from the apparent displacement of previous structures and/or from the type of newly created structures observed on the fault planes. Most of the normal fault planes observed at Sites 832 and 833 exhibit slickensides and most of the strike-slip fault planes observed at Site 833 exhibit lineations and steps resulting from riedel shears. Numerous inverse methods have been developed for determining regional stresses from fault slip data sets (Carey and Brunier, 1974; Angelier, 1979; Carey-Gailhardis and Mercier, 1987). In this paper we present the results from numerical determination of the stress tensor using the computer program of Carey-Gailhardis and Mercier (1987; Table 2). The graphical method of Angelier and Mechler (1977) has been also used to determine the pression and tension areas. We used all the striated fault planes that could be reoriented and along which the sense of motion could be determined. No selection criteria was employed except for the sense of motion on the fault planes from Hole 833B where the normal faults

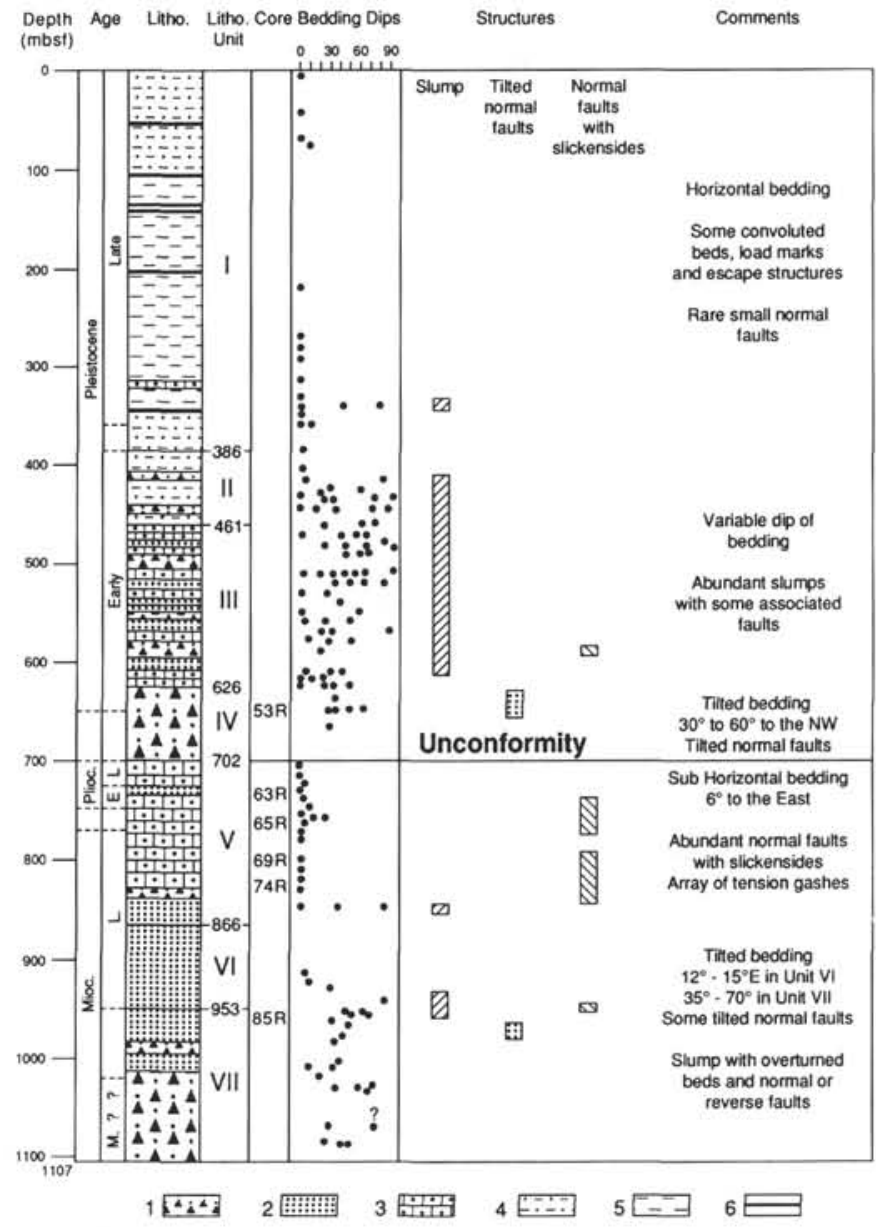

Figure 5. Lithostratigraphic and structural synthetic log of Site 832. The structural data are based only on core observations. $1=$ basaltic breccia and volcanic sandstone; 2 = volcanic sandstone; $3=$ calcareous silty mixed sedimentary rock; $4=$ siltstone; $5=$ clayey silt and silty clay; $6=$ volcanic ash.

have been separated from the strike-slip and reverse faults. The data have been regrouped by core, or several successive cores, depending on the homogeneity of the fault population and the depth range.

\section{STRUCTURAL OBSERVATIONS AND INTERPRETATION AT SITE 832}

Site 832 is located on flat basin floor within the center of the North Aoba Basin at 3090 mbsl (Figs. 1 and 2). Multichannel seismic lines crossing over the basin and Site 832 (Figs. 2 and 4) show a major angular unconformity at $4.8 \mathrm{~s}$. The primary goal of drilling at Site 832 was to penetrate and date this unconformity, which is latest Pliocene or earliest Pleistocene in age and may be correlated with the onset of d'Entrecasteaux Zone-New Hebrides Arc collision (Collot, Greene, Stokking, et al., 1992). Based on the bedding strike and dip, the type of structural features, as well as the lithostratigraphy, the column drilled at Site 832 can be divided into five parts which largely correlate with the lithostratigraphic units. All deformational structures result from small- to large-scale slumping, tilting, and normal microfaulting (Fig. 5).

\section{Tilting, Slumping, Unconformities, and Correlation with Seismic Reflection Data}

The first 400-m-thick deposits drilled are mainly composed of upper Pleistocene sandy, silty, and clayey volcaniclastic sediments (lithostratigraphic Unit 1) and are dominated by horizontal bedding 


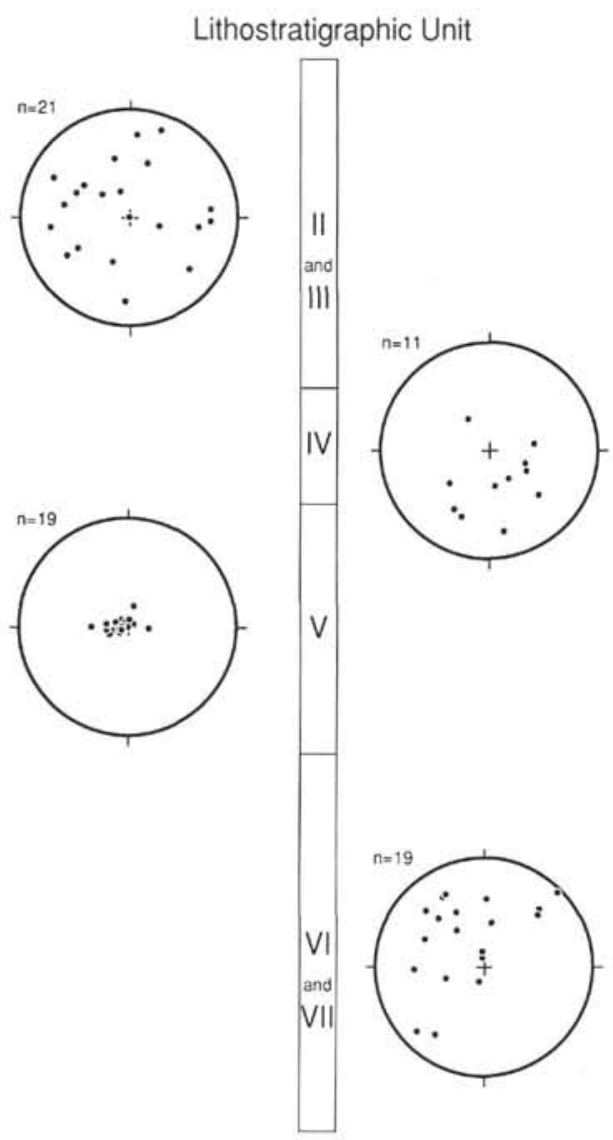

Figure 6. Equal-area plots of poles of the paleomagnetically-reoriented bedding planes measured in lithostratigraphic units of Hole 832B. $n=$ number of samples per plot.

planes (except at levels of rare small slumps). They correlate well with an $0.5 \mathrm{~s}$ interval zone of horizontal, parallel, and continuous reflections in the seismic reflection profile (Fig. 4).

The 225-m-thick lower Pleistocene calcareous volcanic mixed sedimentary rocks interbedded with volcanic sandstones and breccias (lithostratigraphic Units II and III) are characterized by a large variation in the bedding plane dips (from horizontal to vertical) and correlate with an almost $0.2 \mathrm{~s}$ weakly reflective zone observed above the unconformity in the seismic reflection profile (Fig. 4). Slump fold hinges were frequently observed in cores, and thus the attitudes of bedding planes are attributed to slumping. Although rotation of planes due to slumping cannot be ruled out, the paleomagnetically reoriented measurements of bedding planes were used to evaluate the slumping direction. The poles of oriented bedding planes from the cores of Units II and III are scattered and no mean bedding dip direction or fold axis orientation can be reasonably estimated (Fig. 6). However, a more detailed observation of six different slump sequences in lithostratigraphic Unit III reveals that four data sets indicate north-south to northeast-southwest trending slump axes, the two others giving an east-west and a southeast-northwest trending axis. These structural data may suggest a slumping direction to the south or east, which is in agreement with basin filling from the north or the west.

The 75-m-thick rocks drilled from 625 to 702 mbsf correspond to uppermost Pliocene or lowermost Pleistocene matrix-supported basaltic breccias and volcanic sandstones (lithostratigraphic Unit IV). They also include white clasts of coral and neritic limestones indicating erosion in shallow waters or emergent land areas. The bedding, observable in the rare intervals of laminated siltstones in the top ( 627 to $628 \mathrm{mbsf}$ ) and middle (648 to $653 \mathrm{mbsf}$ ) of Unit IV is always significantly inclined with dips from $25^{\circ}$ to $65^{\circ}$. After reorientation, the dip direction of most of the bedding planes ranges from northeast to west (Fig. 6). The bedding attitude observed in the cores is in agreement with the in-situ FMS data, which indicate around $650 \mathrm{mbsf}$ strikes ranging from $190^{\circ}$ to $260^{\circ}$ and dips from $20^{\circ}$ to $60^{\circ}$ toward the west-northwest and north (Figs. 7 and 8). Also a few bedding planes dip to the southeast (Figs. 6 and 8). Assuming that the bedding attitude is due to deformation (presumably slumping as suggested by a flat shear plane observed in a core at the base of steeply dipping bed), a northeast-southwest trending slump axis can be deduced. Unit IV is also characterized by the occurrence of tilted conjugate normal faults. These faults are well discernible in the laminated siltstones and sandstones at intervals around $652 \mathrm{mbsf}$ (Fig. 9B). The faults strike parallel to the bedding and can be divided into two sets: one that dips steeply $\left(50^{\circ}\right.$ to vertical $)$ and shows normal, vertical, or even apparent reverse motion, whereas the other dips gently $\left(10^{\circ}\right.$ to $\left.40^{\circ}\right)$ and shows a normal sense of motion. When the bedding is restored to horizontal, both sets of faults indicate a normal displacement and dip steeply in opposite directions, indicating that the rocks were affected by normal faulting prior to tilting.

The contact at 700 mbsf between the breccias of Unit IV and the underlying 150-m-thick upper Miocene to upper Pliocene sequence of silty chalks and calcareous volcanic mixed sedimentary rocks (lithostratigraphic Unit V) correlates with the major angular unconformity observed in the seismic reflection profile at $4.8 \mathrm{~s}$ (Fig. 4). This unconformity, which corresponds in age to that of the Pliocene/Pleistocene boundary, resulted from an eastward tilt of the basin deposits and is marked by a drastic change in the sedimentation from quiet calcareous (Unit V) to debris flow and turbiditic deposits (Units IV, III, and II). Below the unconformity, the bedding dips very gently $\left(5^{\circ}-6^{\circ}\right)$ toward the east (N95-100 ${ }^{\circ} \mathrm{E}$ ) (Table 1 and Figs. 6, 7, and 8), which is similar to the apparent angle of a strong reflection that marks the unconformity. Steeper bedding dips (up to $30^{\circ}$ and with the same direction) are restricted to the 750-770 mbsf interval (Fig. 7).

Below the calcareous rocks of Unit V, 100-m-thick upper Miocene volcanic sandstones were drilled from 850 to $950 \mathrm{mbsf}$ (lithostratigraphic Unit VI). These rocks (about $0.07 \mathrm{~s}$ thick) correlate with the east-dipping discontinuous reflections that parallel the strong reflection at the base of the major unconformity (Fig. 4). They dip $12^{\circ}-15^{\circ}$ on average toward the northeast and southeast (Fig. 7). However, large variation in bedding dip from $10^{\circ}$ to $65^{\circ}$ is attributed to slumping.

Below $950 \mathrm{mbsf}$, the 150 -m-thick sequence of basaltic breccias with some sandstones and siltstones (lithostratigraphic Unit VII) is of an uncertain age since most of the rocks recovered in drilling are barren. Microfossils suggest a latest early to early middle Miocene age (Collot, Greene, Stokking, et al., 1992). However, a K-Ar date determined from basaltic pebbles recovered at the base of the breccias ( $1100 \mathrm{mbsf}$ ) gives an age of $5.66 \pm 0.85 \mathrm{Ma}$ (Rex et al., this volume), indicating that the microfossils are reworked and the Unit VII is latest Miocene in age. The bedding dip average $50^{\circ}$ (ranges $35^{\circ}$ to $70^{\circ}$ ) and the dip directions are extremely variable (Figs. 7 and 8 ). A slump fold hinge was observed at the base of a 2-m-thick overturned sequence at 957 mbsf (Fig. 9A). Microfaults with normal, strike-slip, or reverse sense of movement are locally associated with the slumps. Unit VII is also characterized by the occurrence of tilted conjugate normal faults (Fig. 5). Although slumps have been recognized in Units VII and VI, FMS data reveal a difference in the mean bedding dip between rocks of Units VI that dip $12^{\circ}$ on average and underlying rocks of Unit VII that dip steeper $\left(35^{\circ}\right.$ to $70^{\circ}$ ) (Figs. 7 and 8 ). A possible unconformity may exist at $950 \mathrm{mbsf}$, at the contact between Units VI and VII, which would exist according to velocity data (Collot, Greene, Stokking, et al., 1992) around the traveltime of $5 \mathrm{~s}$. The seismic reflection profile shows gently dipping and steeper inclined discontinuous reflections above and below this depth, respectively (Fig. 4). This possible unconformity dates from the late Miocene according to the $\mathrm{K}$-Ar radiometric age. In any case, Units VI and VII must be interpreted as debris flows and recorded a late Miocene tectonic or magmatic event. 


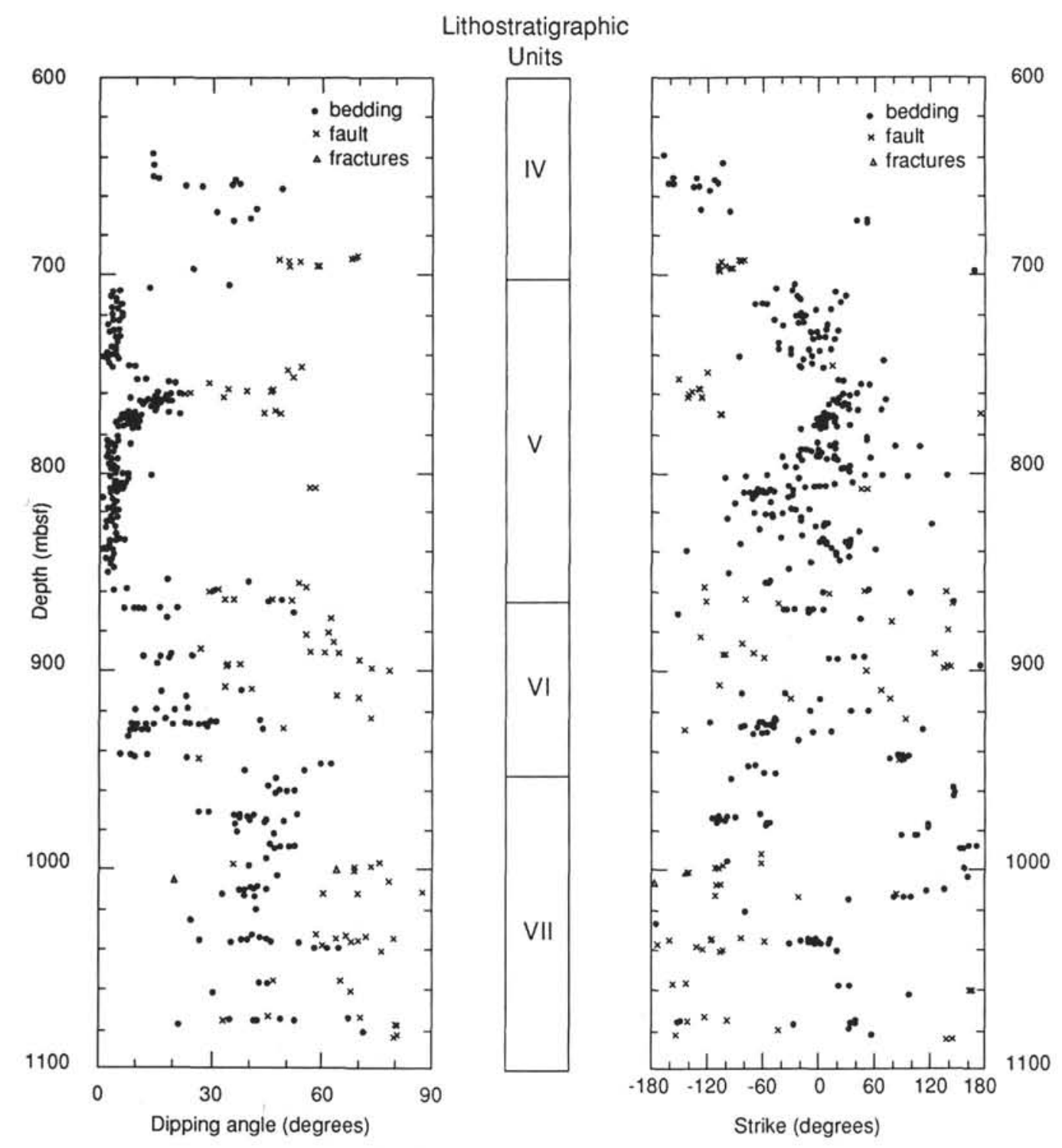

Figure 7. Structural data obtained from FMS images in Hole 832B.

\section{Normal Microfaulting}

Normal microfaults with well developed slickensides are mainly restricted to lithostratigraphic Unit V (Fig. 5). Small scale (1 to $6 \mathrm{~cm}$ long) veins, and sometimes larger veins filled with gypsum were frequently observed in association with the normal microfaults. The small veins outlined by darker material are planar to sigmoidal with bifurcated ends and vertical to oblique with respect to the bedding (Fig. 9C). The veins form tension gashes arrays parallel with the bedding, indicating bedding-parallel extension. Microfaults occur only below 740 down to $850 \mathrm{mbsf}$. They are especially abundant between 740 and 770 mbsf (Cores 134-832B-63R to -65R) and also, with lower frequency, between 798 and 850 mbsf (Cores 134-832B-69R to -74R). Slickensides, mostly with vertical pitch, have been observed on most of the fault planes. Bedding offsets and steps on thinly mineralized fibers that coat the fault planes always indicate a normal sense of motion with displacements on the order of millimeters.

After orientation, the faults strike from north-northwest-southsoutheast to northeast-southwest (Fig. 10). They are conjugate and have average dips from $20^{\circ}$ to $50^{\circ}$ toward the west and northwest or east and southeast, the former group being more abundant. FMS data reveal faults with similar strikes and dips at depth of 740-770 mbsf, where bedding dips slightly increase (Figs. 7 and 8 ).

Estimation of stress tensor from striated normal fault planes in Unit $\mathrm{V}$ are reported in Table 2. The compressional axis is vertical and the tensional axis trends east-northeast-west-southwest or east-southeast-west-northwest depending on cores or group of cores. The faults in Cores $134-832 \mathrm{~B}-63 \mathrm{R}$ to $-65 \mathrm{R}$ ( 741 to $767 \mathrm{mbsf}$ ) give an east-northeast-west-southwest tensional axis (Fig. 10), whereas the faults in Cores $134-832 \mathrm{~B}-69 \mathrm{R}$ to $-74 \mathrm{R}$ ( 779 to $850 \mathrm{mbsf}$ ) give an east-southeast-west-northwest tensional axis (Fig. 11). Although the tensional axis varies in azimuth, the stress tensor solutions are not in contradiction because the intermediate (sigma 2) and the tensional (sigma 3 ) principal stresses are very similar in magnitude, with $R$ values ranging from 0.98 to 0.99 .

Normal microfaults are restricted to the upper Miocene to lower Pliocene sequence of calcareous sedimentary rocks, suggesting that the rock type is one of the controlling factors for fault occurrence. Faults first appear at $740 \mathrm{mbsf}, 40 \mathrm{~m}$ below 300 -m-thick lower Pleistocene debris flows and turbidites including 76-m-thick basaltic breccias and volcanic sandstones at the base (lithostratigraphic Unit IV). Normal faults likely are due to the weight of the overlying sedimentary col- 


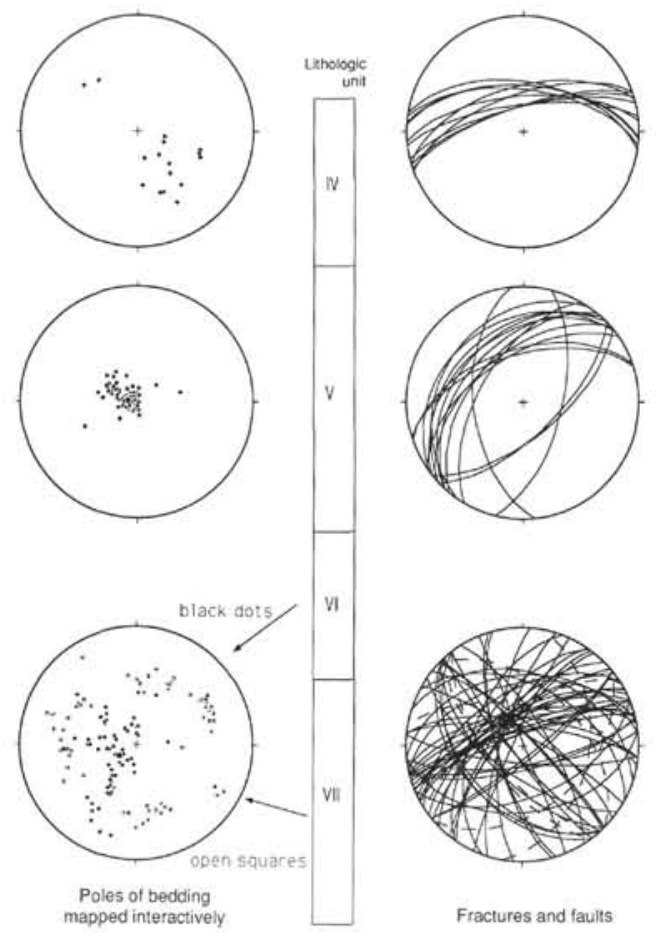

Figure 8. Equal-area plots of bedding and fault planes mapped interactively on FMS images from different Units of Hole 832B. In the lower left plot, black dots and open squares correspond to poles of bedding planes from Units VI and VII, respectively. Filled square in the central left plot corresponds to the mean pole that is reported in Table 1.

umn and are interpreted to be the result of catastrophic deposition of the volcanic breccia and sandstone. If this interpretation is correct, the maximum age for the normal faulting would be latest Pliocene or earliest Pleistocene at Site 832.

\section{STRUCTURAL OBSERVATIONS AND INTERPRETATION AT SITE 833}

Site 833 is located on the lower part of the eastern flank of the North Aoba Basin at 2630 mbsl, northwest of Maewo Island (Figs. 1 and 2). A Seabeam bathymetric map (Fig. 12), as well as several multichannel seismic reflection profiles (Fig. 13) indicate that a succession of north-northwest-south-southeast-trending antiforms and synforms formed along the western flank of the Maewo ridge and that compressive deformation is still active, the seafloor sediments being involved (Katz, 1988; Daniel et al., 1989). The primary objective at Site 833 was to penetrate older sequences than Site 832 . However, the deepest drilled rocks at Site 833 date from the early Pliocene. Deformational structures observed at Site 833 result from slumping, tilting, normal microfaulting, strike-slip and reverse faulting. Attitudes of the bedding plane as well as type and distribution of structural features with depth are reported in Figure 14.

\section{Tilting and Slumping}

Compared with Site 832 , Site 833 is characterized by much more coherence in the attitude of bedding planes although beds generally dip steeper. Dip angles increase downhole (Fig. 14): about $10^{\circ}$ in lithostratigraphic Units I and II (0-376 mbsf), $10^{\circ}$ to $20^{\circ}$ in Units III and IV (376-830 mbsf), and $20^{\circ}-25^{\circ}$ in Unit V (830-1000 mbsf). Strikes and dips of the bedding planes oriented from paleomagnetic

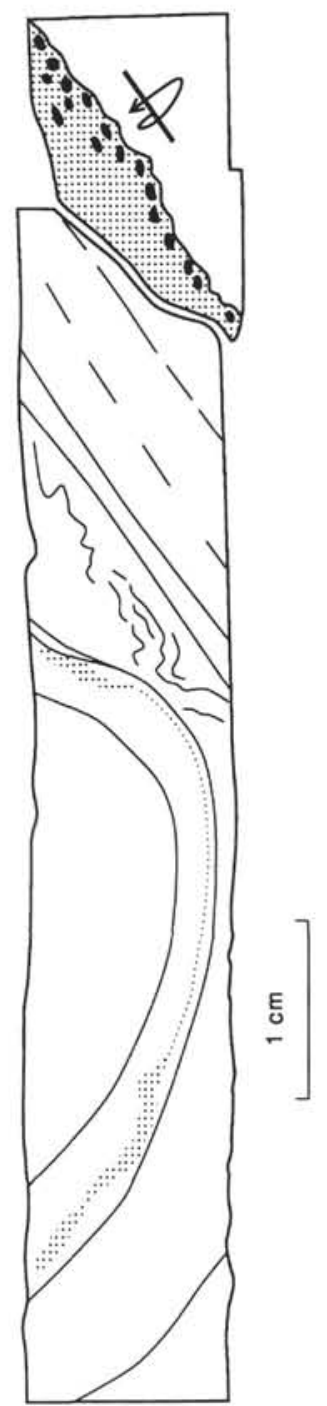

A

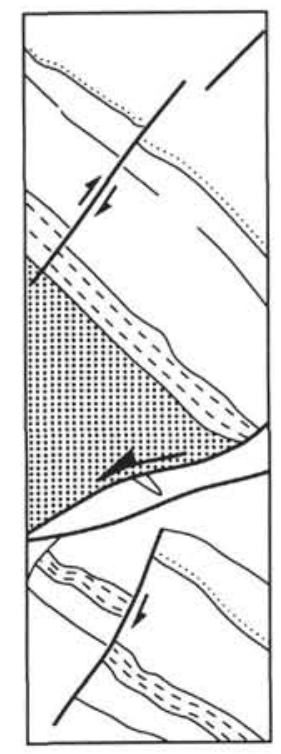

Ė]
Figure 9. Examples of structural features observed at Hole 832B. A. Slump fold and overturned sequence recovered in Section 134-832B-85R-4, top of lithostratigraphic Unit VII. B. Tilted conjugate normal faults in Section 134-832B53R-6, lithostratigraphic Unit IV. C. Slickensided normal faults associated with an array of tension gashes in Section 134-832B-64R-1, lithostratigraphic Unit V. Location of cores is shown on Figure 5.

data are quite constant and in very good accordance with the FMS data (Table 1 and Figs. 15, 16, and 17). Bedding dip directions range from southwest $\left(217^{\circ}\right)$ to west $\left(279^{\circ}\right)$, and most of the beds dip $10^{\circ}-20^{\circ}$ toward the west-southwest $\left(250^{\circ}\right)$.

However bedding attitude varies widely at some levels. Slumps occur between 250 and 300 mbsf in Unit II. Frequent slumps, convoluted bedding, and tilted conjugate normal faults were observed at $565-580 \mathrm{mbsf}$ in upper Pliocene volcanic sandstones and breccias near the base of the Unit III (Fig. 14). At this level, bedding planes strike from $70^{\circ}$ to $120^{\circ}$ and dip up to $50^{\circ}$ toward the south (Figs. 15, 16, and 17). Also, bedding variation occurs in the Unit IV (especially from 747 to $770 \mathrm{mbsf}$ and from 800 to $830 \mathrm{mbsf}$ ), where some bedding planes dip steeply toward the southeast and northwest (Fig. 16). Slumps and convoluted bedding have been noted at these levels. The lower part of Unit IV, below $762 \mathrm{mbsf}$, is characterized, in comparison with the upper 

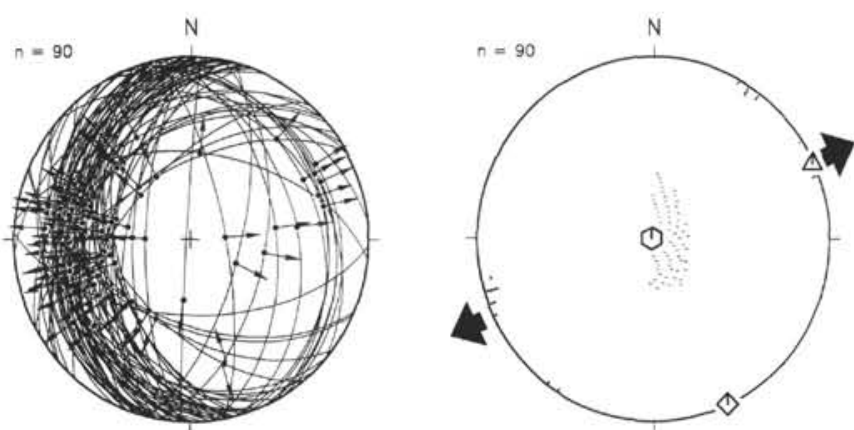

Figure 10. Stereographic diagrams illustrating the stress tensor determination from striated normal faults observed in Cores 134-832B-63R to $-65 \mathrm{R}$, lithostratigraphic Unit V (location of cores is shown on Fig. 5). Equal-area lower hemisphere projection. Data ( 90 fault planes with slickensides) are plotted on the left. The plot on the right shows the principal stress axes obtained from inversion method (sigma 1,2, and 3 axes correspond to hexagon, diamond, and triangle symbols, respectively) as well as zones of pression $(-)$ and tension (+) obtained from $\mathrm{P}$ and $\mathrm{T}$ dihedra graphical method.

part, by a strong decrease in the number of bedding planes detected by FMS and by an increase in bedding dip (Fig. 16). Poles of bedding planes of the Unit IV cluster along a great circle (Figs. 15 and 17). If we assume that this distribution is due to folding, the fold axis gently plunges toward the south-southwest $\left(210^{\circ}-220^{\circ}\right)$. The FMS images show at 748-749 mbsf a fold axis that plunges $6^{\circ}$ toward $216^{\circ}$.

In Unit V, lower Pliocene sedimentary rocks are present from 880-910 and 934-945 mbsf, between volcanic sills also dated from the early Pliocene by K-Ar method (3.3,3.6 Ma, respectively; Rex, this volume). In these levels, bedding generally dips about $20^{\circ}-30^{\circ}$ to the west. However, a systematic decrease of the dip angle occurs close to the sill layers (Fig. 16): around $835 \mathrm{~m}$ above the first sill, at 885 below the first sill, and at $910-915$ above the second sill. Distorted beds have been noted between the two sills; bedding dip angles reach $50^{\circ}-60^{\circ}$, although the bedding strike remains constant.

\section{Normal Microfaulting}

Microfaults with well-developed slickensides of calcite fibers are mainly restricted to the calcareous rocks of Unit IV and occur only below $628 \mathrm{mbsf}$ (Fig. 14). They are especially abundant at 665-675 mbsf (Cores 134-833B-64R to -65R), 760-784 mbsf (Cores 134833B-74R to -76R), and 818-823 mbsf (Core 134-833B-80R). Slickensides indicating dip slip motion have been observed on most of the fault planes. Bedding offsets and steps on the thin mineralizations that coat the fault planes always indicate a normal sense of motion with displacements on the order of millimeters to centimeters. Frequent planar to sigmoidal veins oblique to the bedding, and mainly arranged in arrays, are associated with the normal microfaults (Fig. 18A). Vein arrays are always parallel with the bedding, even when bedding dips, indicating that the veins and the normal faulting were formed before the tilting of the bedding.

Strikes of the normal faults, after orientation using paleomagnetic data, mainly range from east-west to east-southeast-west-northwest (Fig. 19). However, northeast-southwest trending faults also exist, especially around 771-805 mbsf (Cores 134-833B-75R to -78R). These faults are conjugate and dip on average $40^{\circ}-60^{\circ}$ toward the north-northeast and south-southwest. Fault planes recorded by FMS in the Unit IV can be divided in two sets: one strikes north-south and the other east-southeast-west-northwest (Fig. 17).

Stress tensor solutions from striated normal fault planes observed in different cores of Units IV and V are reported in Table 2. The subhorizontal tensional stress axis trends north-northeast-south-south-
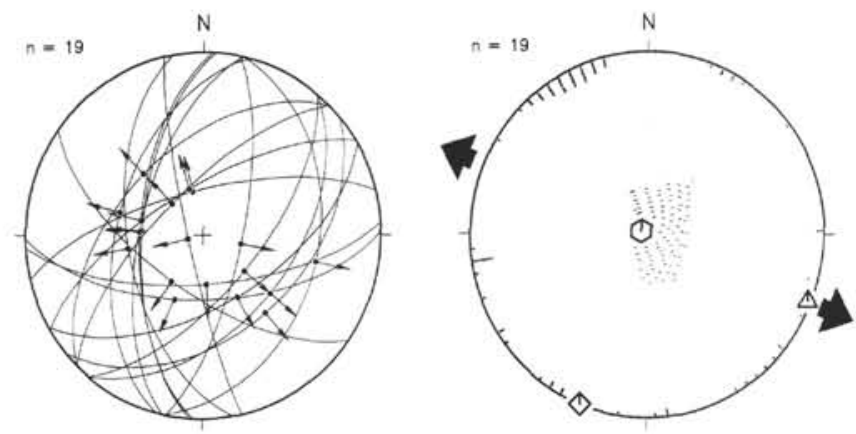

Figure 11. Stereographic diagrams illustrating the stress tensor determination from striated normal faults observed in Cores 134-832B-69R to -74R, lithostratigraphic Unit V. Same legend as Figure 10.

west or east-southeast-west-northwest depending of cores or group of cores (Fig. 19). East-southeast-west-northwest tensional axis is found for Cores 134-833B-75R to -78R, in which strikes of the faults show a large variation and bedding dips are greater than above (Fig. 16). The difference in the stress tensors solutions is, as in Site 832, a change in direction between the intermediate and the tensional stress axes. Therefore, $\mathrm{R}$ values are in general close to 1 , indicating that sigma 2 and 3 are similar in magnitude and that normal faulting mainly results from uniaxial stress. The compressional axis is not vertical, but almost systematically deviates $10^{\circ}-15^{\circ}$ from the vertical and plunges toward the south or east (Table 2). The deviation increases downhole and especially at 762 mbsf between Cores 134-833B-74R and $-75 R$, which coincides with the increase of westward bedding dips in Unit IV. As the deviation of P axis from vertical is equivalent to the bedding dip angle, and the $\mathrm{P}$ axis plunges in opposite direction to the bedding dip, we infer that the tilting of the sedimentary layers postdates normal faulting.

The normal microfaults occur in lower Pliocene to lowermost Upper Pliocene calcareous and volcanic sandstones to claystones (lithostratigraphic Unit IV). They first appear at a depth of $628 \mathrm{~m}, 50$ $\mathrm{m}$ below 200-m-thick upper Pliocene sequence of volcanic sandstone and fine-grained basaltic breccia (Unit III). The normal faults are interpreted to be the result of overloading, due to the rapid deposition of the 200-m-thick overlying volcaniclastic sequence. The age for the normal faulting is thus considered as late Pliocene at Site 833.

\section{Strike Slip and Reverse Faulting}

In comparison with Site 832 , Site 833 is characterized by the presence of strike-slip and reverse faults. These structures, although occurring sporadically throughout the Holes $833 \mathrm{~A}$ and B, are better expressed below $760 \mathrm{mbsf}$ and are particularly abundant below 830 mbsf (Fig. 14). In Unit II, scaly fabrics dipping $20^{\circ}$ and reverse microfaults dipping $30^{\circ}-35^{\circ} \mathrm{E}$ occur at 95 and $191 \mathrm{mbsf}$, respectively, in Sections 134-833A-16X-2, -16X-3, and 26X-I (Fig. 18B). A 4-mthick deformed zone with no clear planar orientation was also recovered at 204-208 mbsf in Sections 134-833B-14R-1 to -4. Such structural features observed at about the same depth in both Holes $833 \mathrm{~A}$ and B suggest that they are not drilling induced, but result from tectonics. A thrusting or a sliding plane is thus proposed to exist around 200 mbsf. In Unit IV, strike-slip faults with a small component of reverse motion have been observed at $370,680,763,818$, and 820 mbsf. In the latter four cases, horizontal slickensides are superimposed on normal fault planes that bear previous vertical slickensides, indicating that strike-slip faulting occurs along reactivated fault planes and postdates normal faulting.

Rocks of Unit V, which mainly consists of volcanic sills, are highly fractured. Broken pieces of volcanic rocks recovered in the cores 


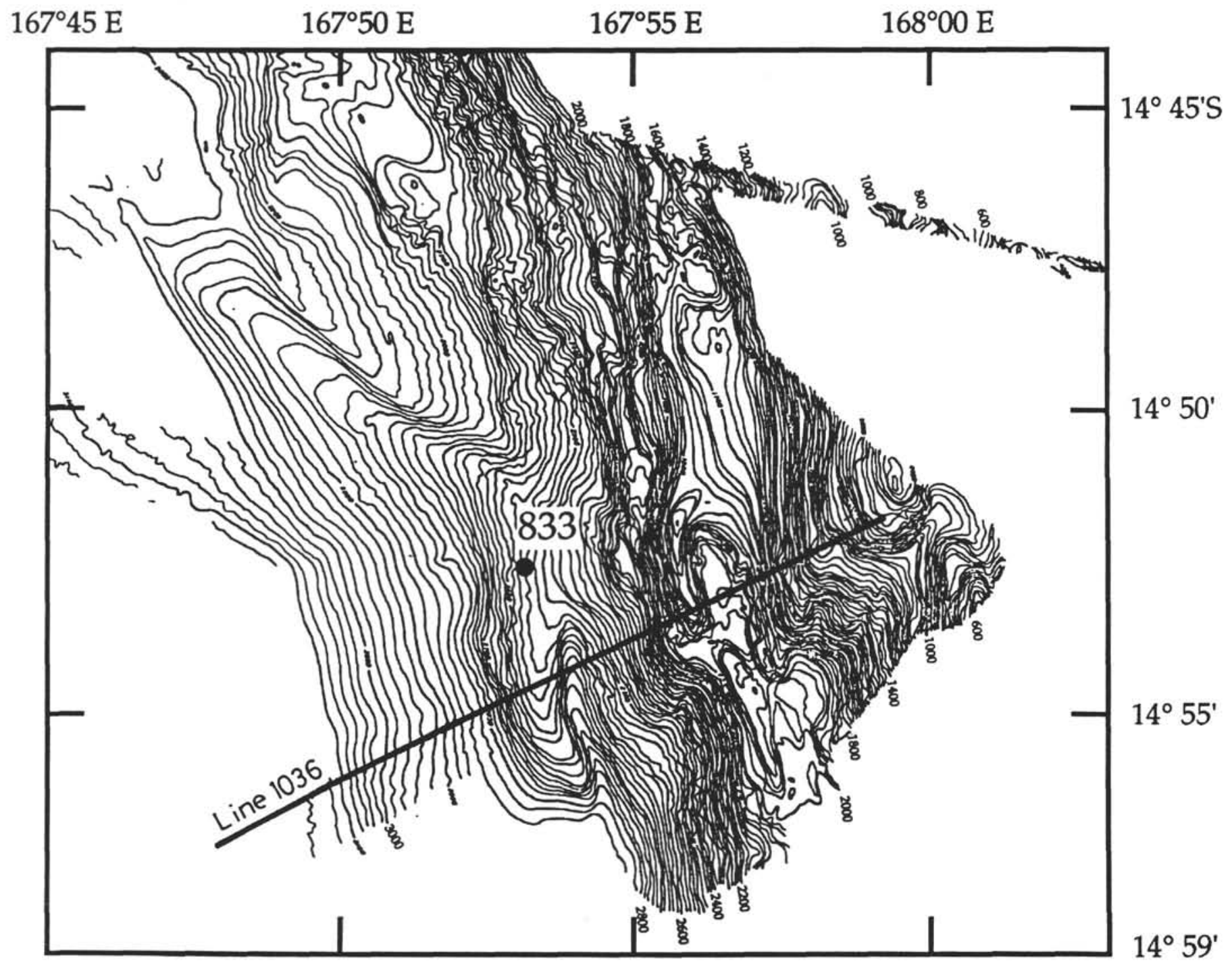

Figure 12. Seabeam bathymetric map near the location of Site 833, along the eastern edge of the North Aoba Basin (from Daniel et al., 1989).

exhibit numerous fault planes. The sense of motion, mostly deduced from riedel shear-induced steps, mainly indicates strike-slip displacement with a reverse component (Fig. 18C). The faults and fractures imaged by FMS are plotted on Figure 20. Although they are scattered, they can, however, be divided into three groups: one group strikes north-south and dips to the west, the other two strike east-west and dip either north or south. A similar plot is obtained for the faults and fractures of the overlying Unit IV.

Only nine faults with unambiguous sense of motion can be oriented and used to determine the orientation of the compressive stress axis (Table 2 and Fig. 20). Eight of these faults were recovered in the deeper part of the Hole $833 \mathrm{~B}$, below $680 \mathrm{~m}$ in the Units IV and V. One of these faults is located at the base of Unit II (Section 134-833B-3IR-3, $370 \mathrm{mbsf}$ ). The compressional axis is subhorizontal and lies between northeast-southwest and east-northeast-west-southwest. Although this result is weakly constrained due to the scarcity of data, it is in accordance with the tilting direction of the sedimentary layers (toward $\mathrm{N} 250^{\circ}-260^{\circ} \mathrm{E}$ ), with the direction of anticlinal ridge axes on the bathymetric map ( $150^{\circ}$ to $170^{\circ} \mathrm{E}$ : Daniel et al., 1989; Fig. 12), and with the direction of horizontal compressional stress found in the borehole using breakouts $\left(79^{\circ} \mathrm{E} \pm 8^{\circ}\right)$ and vertical fractures $\left(70^{\circ} \mathrm{E} \pm 5^{\circ}\right)($ Chabernaud and Krammer, this volume). The direction of compression is also parallel to the elongated shape of the Aoba Island, an active volcano (Fig. 1), and is close to the azimuths of $\mathrm{P}$ axis from thrust type focal mechanism solutions for shallow earthquakes occurring below northern Maewo Island (Louat and Pelletier, 1989).

The initial age of the compressive event, which is still active today, can be estimated in several ways. We previously noted that the tilting of the sedimentary layers and the strike-slip faulting postdate the normal faulting, the later being not older than late Pliocene at Site 833. The seismic profile shown in Figure 13 reveals that the thickness of the sequence located at Site 833 below the Pliocene-Pleistocene transition ( $3.8 \mathrm{~s})$ is constant across the eastern flank of the basin, whereas in contrast the thickness of the sequence above increases toward the flat central part of the basin (Daniel at al., 1989). The thickening is especially visible for the most recent layers. The Pliocene/Pleistocene boundary at $3.8 \mathrm{~s}$ at Site 833 correlates with the major unconformity at $4.8 \mathrm{~s}$ at Site 832 (see also Fisher et al., this volume). The Pleistocene section of Site $833(375 \mathrm{~m})$ is about half that at Site $832(700 \mathrm{~m})$, the upper Pleistocene being $150 \mathrm{~m}$ and $375 \mathrm{~m}$, respectively. Correlation of the lithostratigraphy between the two sites also reveals that, contrarily to the Pleistocene section, the Pliocene section increases from the central part of the basin (less than $100 \mathrm{~m}$ thick at Site 832) to the eastern flank of the basin (at least $600 \mathrm{~m}$ thick at Site 833). These observations indicate that an uplift of the eastern side of the basin and a westward shift of the basin depocenter occurred at the time of the Pliocene/Pleistocene boundary. Therefore uplift is clearly marked on the seismic profile by the truncation of sedimentary sequence at the 


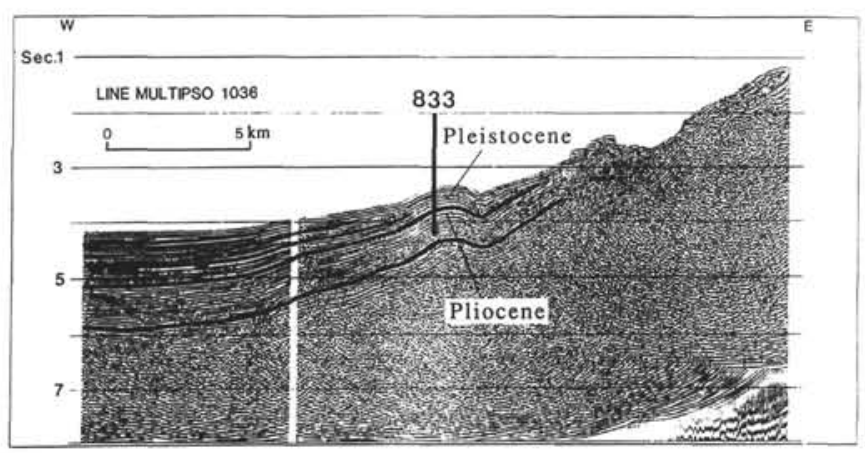

Figure 13. Part of a multichannel seismic reflection profile (Line 1036, Multipso cruise, 1989, ORSTOM) showing the acoustic stratigraphy near Site 833. Note thinning of acoustical units above the Pliocene to Pleistocene boundary toward the east and folding and truncation of units at the seafloor east of Site 833 (from Daniel et al., 1989). Location of the seismic line is shown on Figure 12. seafloor east of the anticline drilled at Site 833 (Daniel at al., 1989; Fig. 13). The onset of compressive deformation, which characterizes the eastern part of the North Aoba Basin at Site 833, is inferred to be around the time of the Pliocene/Pleistocene boundary.

\section{DISCUSSIONS, CORRELATIONS WITH ONSHORE GEOLOGY AND CONCLUSIONS}

The deep-water Aoba Basins recorded a complete tectonic and volcanic history of the New Hebrides Island Arc, because they are ideally located in the middle part of the arc, between the emerged Western and Eastern Belts, and are intruded by the active volcanoes of the Central Chain. Drilling in the North Aoba Basin provided the first continuous stratigraphic section of the area from the latest Miocene. These drilling results will be compared below (Fig. 21) with the onshore geology described in reports of different islands and summarized by Macfarlane et al. (1988).

The volcanic breccia and sandstone containing clasts of basalt dated from the latest Miocene, drilled in the deepest part of Site 832

Structures

Comments

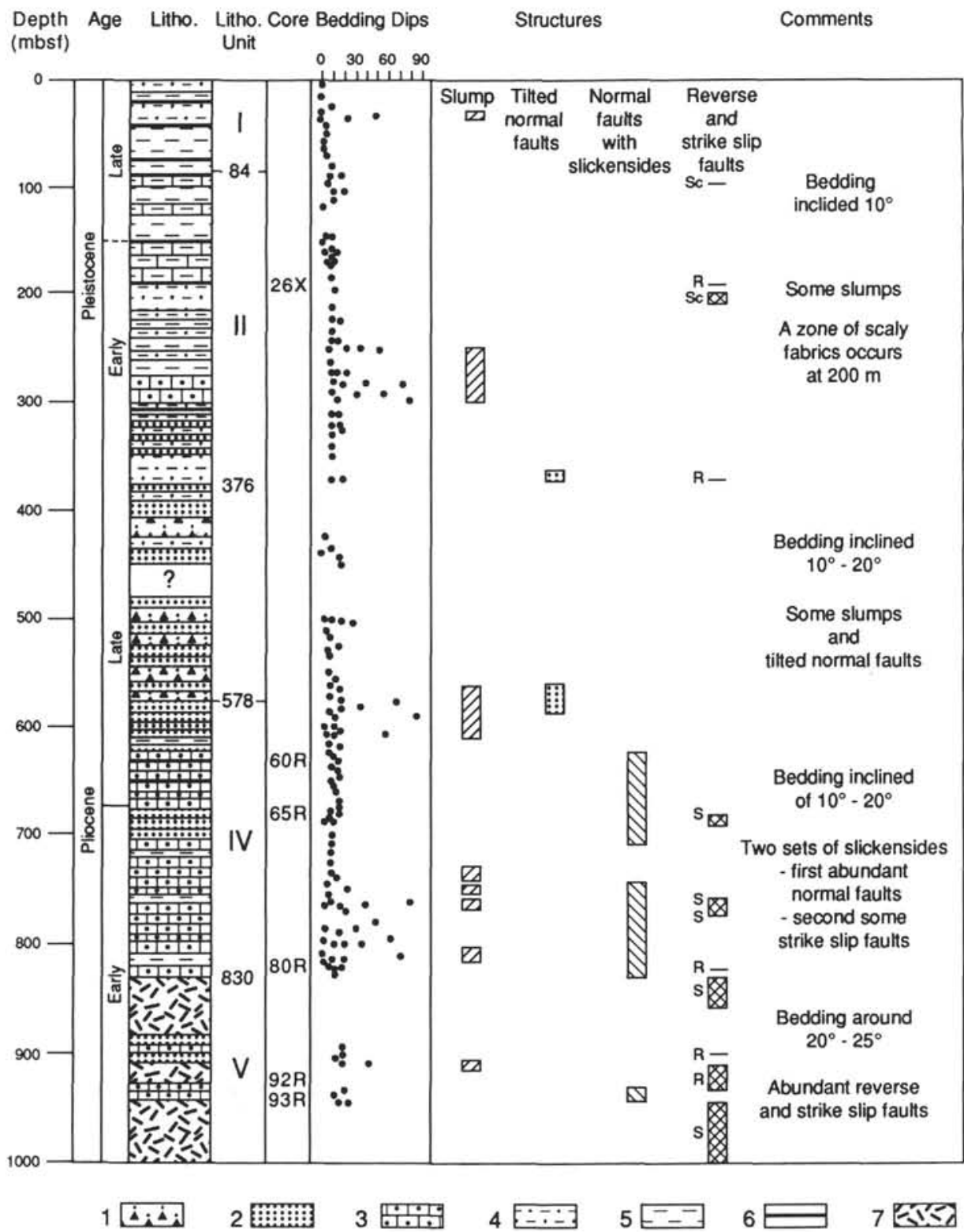

Figure 14. Lithostratigraphic and structural synthetic log of Site 833. The structural data are based only on core observations. 1 = basaltic breccia and volcanic sandstone; 2 = volcanic sandstone; $3=$ calcareous silty mixed sedimentary rock; $4=$ siltstone $; 5=$ clayey silt and silty clay; $6=$ volcanic ash; $7=$ basaltic sill. 
Lithostratigraphic Unit

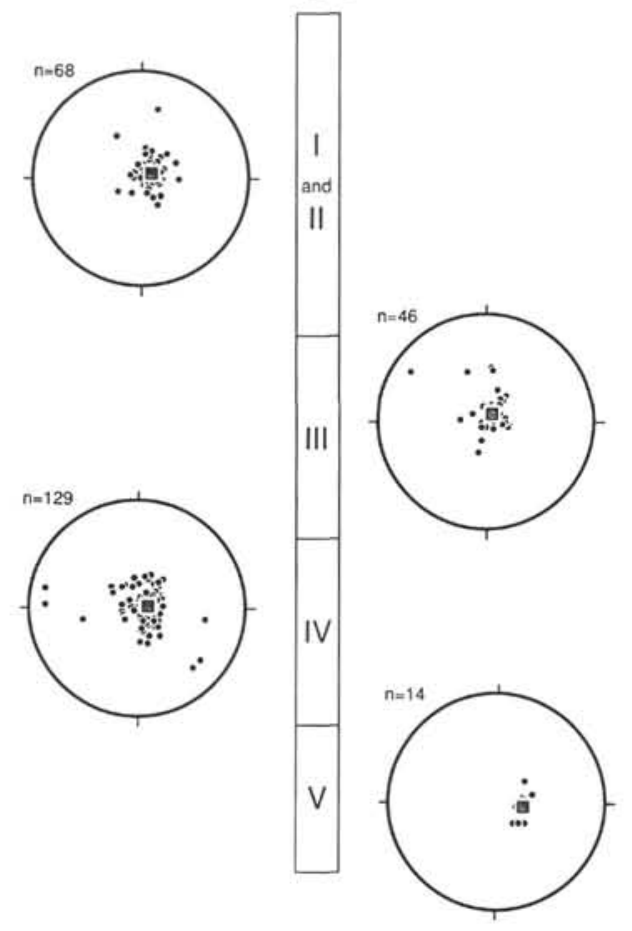

Figure 15. Equal-area plots of poles of the paleomagnetically-reoriented bedding planes measured in lithostratigraphic Units of Hole 833B. $n=$ number of samples per plot. Squares on plots correspond to the mean poles that are reported in Table 1.

below upper Miocene calcareous rocks, must be interpreted as upper Miocene debris flows and turbidites recording a magmatic and tectonic event. 700-m-thick upper Miocene subaerial to submarine volcanics are known in Pentecost and Maewo islands. The tectonic event occurred on Maewo Island in the late Miocene, immediately before the volcanic phase. Maewo Island is thus a possibility for the source area of the deepest drilled rocks at Site 832. However, in-situ volcanism close to site 832 is also possible. Another possible source could be the deep part of the large Pleistocene volcanoes of the Central Chain (Santa Maria or Aoba) since the oldest rocks of these edifices are unknown. The volcanoes in the central part of the arc could be much more older than previously thought; in the southern part of the arc, upper Miocene volcanism is exposed on the Erromango Island.

At Site 832, located in the central part of the North Aoba Basin, a major unconformity is found at $700 \mathrm{mbsf}$, between a slumped turbiditic sequence of volcanic breccia and sandstone above and calcareous beds gently tilted to the east below. The unconformity dates from latest Pliocene or earliest Pleistocene, and resulted from the uplift of the western part of basin and the tilting of the sedimentary cover. The drilled section correlates well with the stratigraphy on Espiritu Santo Island, where uppermost Pliocene to lower Pleistocene shallow water and regressive sandy sequences diachronously overlie upper Miocene to lowermost Pleistocene calcareous hemipelagic rocks, indicating an uplift about the latest Pliocene to earliest Pleistocene time. Above the unconformity at Site 832, 300-m-thick lower Pleistocene turbidites and debris-flow deposits, including 75 -m-thick basaltic breccias and volcanic sandstones at the base, contain reef limestone clasts, indicating emerged or shallow-water land areas close by. One volcanic clast of the lower Pleistocene breccias yields a radiometric age of $2.8 \pm 0.8$ $\mathrm{Ma}$ (Rex, this volume), suggesting that the sediments could derive from the Central Chain and, probably, from the Santa Maria volcano, which is located just north of Site 832. Direction of slumping supports a northern or northwestern source. The overloading of the thick lower Pleistocene turbiditic deposits is responsible for the occurrence of numerous normal microfaults, $40 \mathrm{~m}$ below the unconformity, in upper Miocene to lower Pliocene calcareous rocks.

At Site 833, located along the eastern edge of the North Aoba Basin, 200-m-thick upper Pliocene deposits of volcanic breccia and sandstone suggest neighboring uplift and tectonic event at that time. This correlates well with the stratigraphy on Maewo Island, where upper Pliocene to lower Pleistocene shallow-water deposits unconformably overlie uppermost Miocene to lowermost upper Pliocene pelagic sedimentary rocks, indicating initiation of uplift in the late Pliocene (about $3 \mathrm{Ma}$ ). At Site 833, abundant normal microfaults, observed in lower Pliocene to lowermost-upper Pliocene calcareous rocks $50 \mathrm{~m}$ below 200-m-thick upper Pliocene breccias and sandstones, are interpreted as the result of overloading of the breccias and sandstones.

At Site 833, strike-slip and reverse faults indicate a northeastsouthwest to east-northeast-west-southwest direction of compression, which is in good agreement with the west-southwest dip direction of the bedding, the direction of the horizontal compressive stress deduced from borehole breakouts, and the bathymetric, seismic-reflection, and seismological data. Initiation of compression at Site 833 postdates the normal faulting, and is more or less synchronous of the formation of the unconformity at Site 832, and is thus latest Pliocene or earliest Pleistocene in age. Compression is still active today, as documented by north-northwest-south-southeast-trending anticlinal ridges along the eastern side of the basin and imaged by seafloor bathymetry and seismic reflection profiles. Present-day compression is also documented by numerous shallow earthquakes located under the Eastern Belt and characterized by thrust-type focal mechanism solutions (Louat and Pelletier, 1989).

Timing and type of deformation observed in the North Aoba Basin are in good agreement with those inferred from onshore geology. Uplift and tilt of the basin's western flank is synchronous with the uplift of the Western Belt. Uplift associated with compression of the basin's eastern flank is slightly younger than the late Pliocene uplift for the Eastern Belt. The depocenter of the North Aoba Basin was shifted westward from Pliocene to Pleistocene times, indicating a strong uplift of the eastern side of the basin at the end of the Pliocene. Compressive deformation and uplift migrated progressively westward inside the basin, as indicated by the offlap of recent deposits along the eastern basin flank (Fig. 13). Although some parts of the Western Belt might have emerged since the early Pleistocene, major areas of the Western Belt, and the whole Eastern Belt rose above sea level since the late Pleistocene (0.5 Ma; Macfarlane et al., 1988). Upper Quaternary reef limestones cap large parts of the island belts and formed terraces that are regionally tilted eastward in the Western Belt and westward in the Eastern Belt (Taylor et al., 1980; Macfarlane et al., 1988). Average Holocene uplift rates are higher than in the previous period and are higher in the Western Belt (1 to $7 \mathrm{~mm} / \mathrm{yr}$; Jouannic et al., 1980) than in the Eastern Belt (1 mm/yr; Taylor et al., 1987).

The peculiar morphology of the central part of the New Hebrides Island Arc, including the Western and Eastern Belts of large islands, the deep water Aoba Basins and the large volcanoes of the Central Chain, is considered a direct consequence of an arc-d'Entrecasteaux Zone interaction (Collot et al., 1985; Taylor et al., 1987; Greene et al., 1988). The overall arc, from the Western Belt to the Eastern Belt across the North Aoba Basin, underwent a synchronous tectonic event at the latest Pliocene time (Fig. 21). Since that time, the entire arc has been subjected to compressional stress and acts as a rigid block. The deep water Aoba Basin corresponds today to a large syncline bounded to the west by the rising Western Belt which overthrusts westward the d'Entrecasteaux Zone along the subduction plane. The basin is also bounded to the east by the emerging Eastern Belt, which backthrusts eastward onto the North Fiji Basin oceanic crust, along the central New Hebrides back-arc thrust zone initiated in the latest Pliocene time 


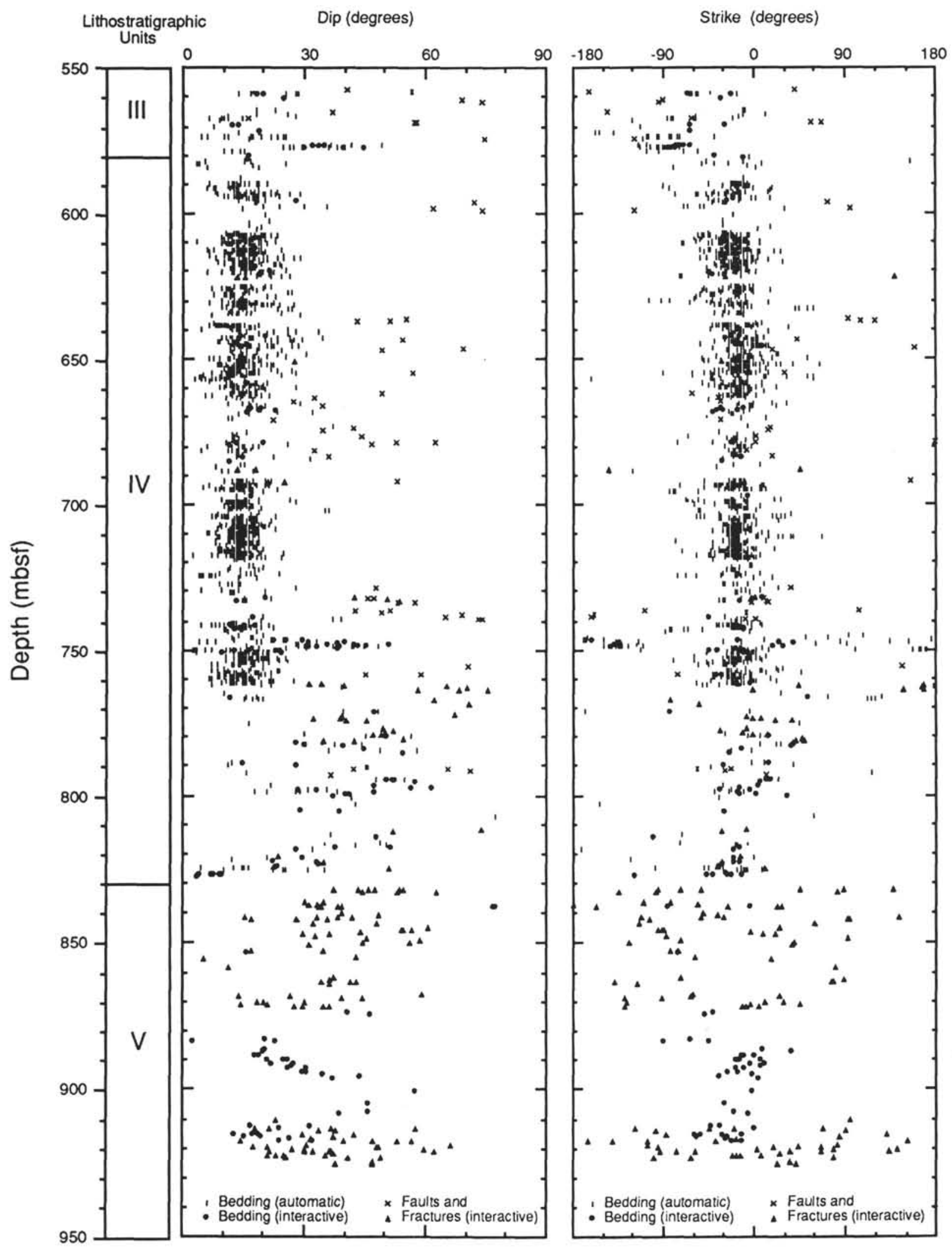

Figure 16. Structural data obtained from FMS images in Hole 833B. 


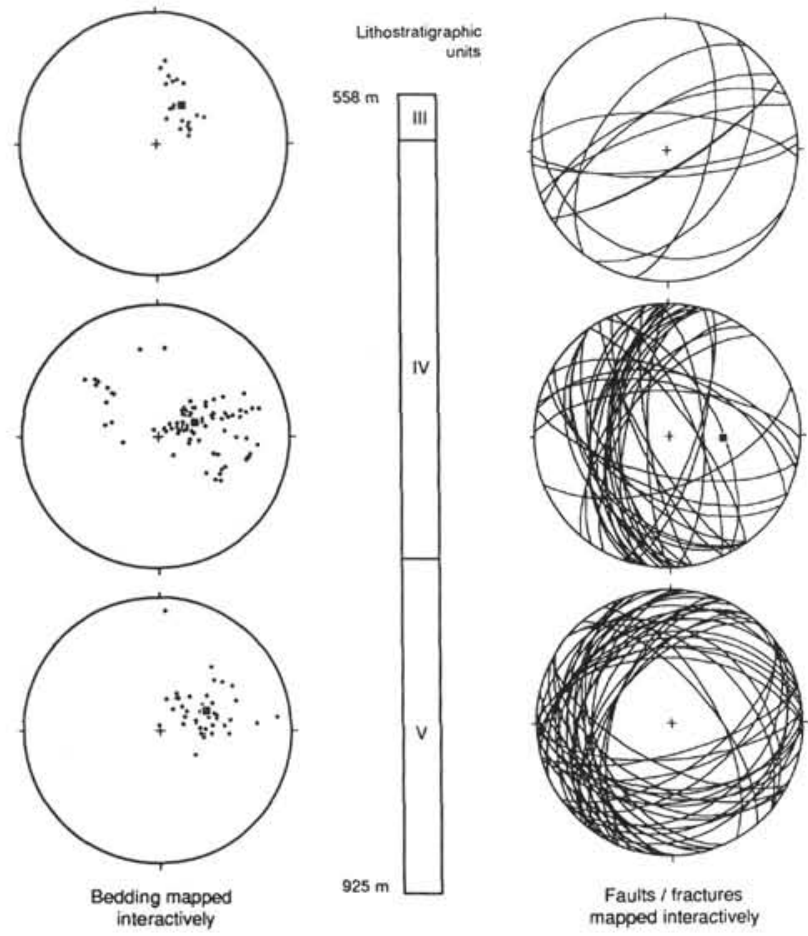

Figure 17. Equal-area plots of bedding and fault planes mapped interactively on FMS images from different Units of Hole 833B. Squares on plots of poles of bedding correspond to the mean poles that are reported in Table 1.

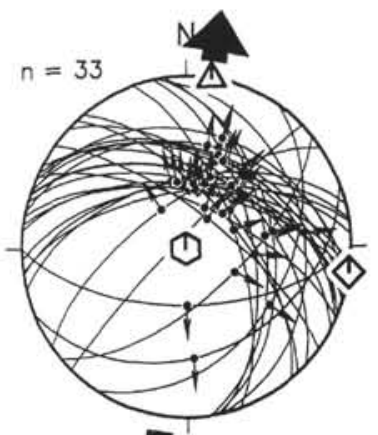

A
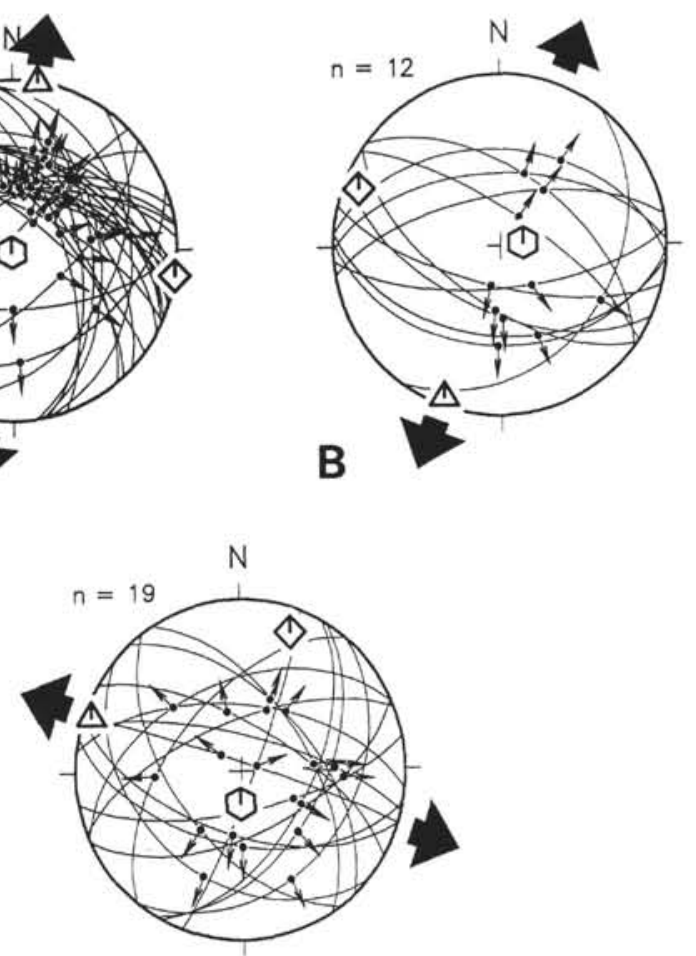

C

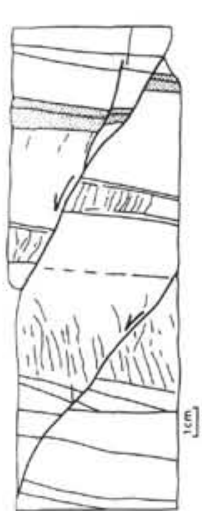

A

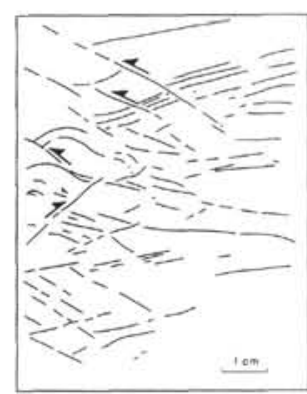

B

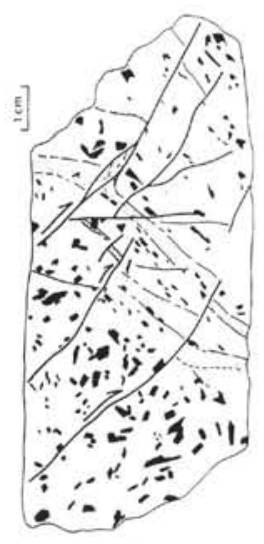

C
Figure 18. Examples of structural features observed at Site 833. A. Striated normal faults and arrays of tension gashes in Section 134-833B-65R-1, lithostratigraphic Unit IV. B. Reverse faults associated with a scaly fabric zone in Section 134-833A-26X-1, lithostratigraphic Unit II. C. Reverse faults in the volcanic sills, Section 134-833B-92R-3, lithostratigraphic Unit V.

and along which ophiolitic rocks exposed on Pentecost Island may have been emplaced.

\section{ACKNOWLEDGMENTS}

We thank Marc Regnier for the use of his program for computing $\mathrm{P}$ and $\mathrm{T}$ dihedra and stereographic plots. We greatly thank E. CareyGailhardis and J.L. Mercier for the use of their stress tensor inversion program. Appreciation is given to John Butsher and J. Perrier for their preparation of some of the illustrations.
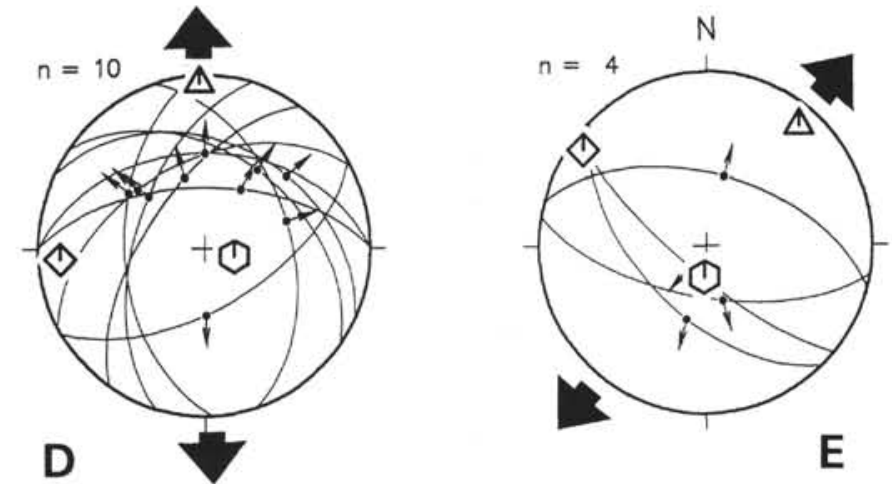

Figure 19. Stereographic plots of the striated normal faults of cores or group of cores in the lithostratigraphic Unit IV of Hole 833B. A. Cores 134-833B-60R to -67 R. B. $-73 R$ to -74 R. C. -75 R to -78 R. D. -80 R. E. $-93 R$. The principal stress axes (sigma 1,2, and 3 ) of the stress tensor obtained by inversion correspond to hexagon, diamond, and triangle symbols, respectively.
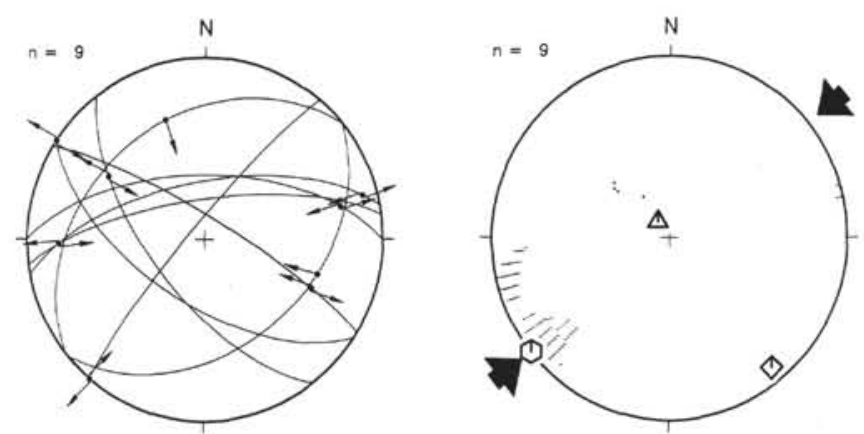

Figure 20. Stereographic diagrams illustrating the stress tensor determination from striated strike-slip and reverse faults observed in Hole 833B. Same symbols as in Figure 10. 

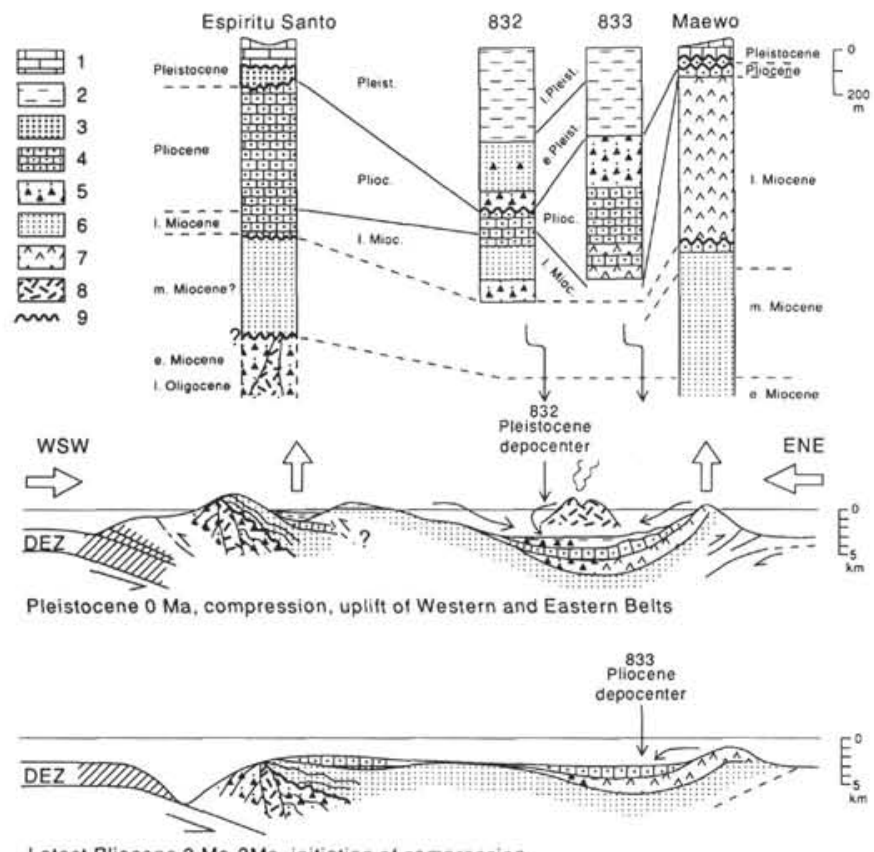

Latest Pliocene $3 \mathrm{Ma}-2 \mathrm{Ma}$, initiation of compression

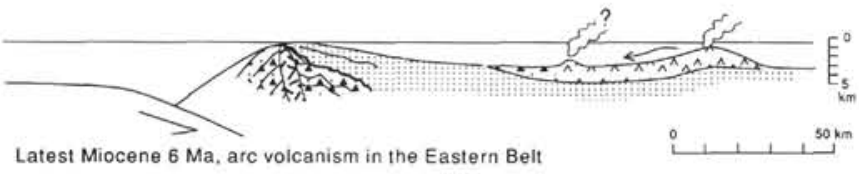

Figure 21. Correlations of North Aoba Basin stratigraphy at Sites 832 and 833 , and onshore stratigraphy, and interpretative sketch of the evolution of the Central New Hebrides Arc since the late Miocene. The present-day stage is based from a cross section around $15^{\circ} \mathrm{S}$. The onshore stratigraphy is from Macfarlane et al. (1988).The thickness of upper Oligocene-lower Miocene and middle Miocene rocks in Espiritu Santo is not at the scale. 1 = reef limestones; 2 = clayey silts and silty clays with ash layers; $3=$ shallow marine and fluviatile silt, sands and conglomerates; 4 = pelagic and hemipelagic sediments, calcareous silty mixed sedimentary rocks; $5=$ volcanic breccias and sandstones; $6=$ volcaniclastics; $7=$ subaerial and submarine volcanics; $8=$ andesitic and basaltic intrusives; $9=$ unconformity.

\section{REFERENCES}

Angelier, J., 1979. Determination of the mean principal directions of stresses for a given fault population. Tectonophysics, 56:T17-T26.

Angelier, J., and Mechler, P., 1977. Sur une méthode graphique de recherche des contraintes principales également utilisable en tectonique et en séismologie: la méthode des dièdres droits. Bull. Soc. Geol. Fr., 19:1309-1318.

Carey, E., and Brunier, B., 1974. Analyse théorique et numérique d'un modèle mécanique élémentaire appliqué à l'étude d'une population de failles. C.R. Acad. Sci. Paris, Ser. D, 279:891-894.

Carey-Gailhardis, E., and Mercier, J.L., 1987. A numerical method for determining the state of stress using focal mechanism of earthquakes populations: application to Tibetain teleseisms and microseismicity of southern Peru. Earth Planet. Sci. Lett., 82:165-179.

Carney, J.N., and Macfarlane, A., 1980. A sedimentary basin in the central New Hebrides Arc. Tech. Bull.-U.N. Econ. Soc. Comm. Asia Pac., Comm. Coord. It. Prospect Miner. Resour. South Pac. Offshore Areas, 3:109-120.

\footnotetext{
- Abbreviations for names of organizations and publications in ODP reference lists follow the style given in Chemical Abstracts Service Source Index (published by American Chemical Society).
}

1982. Geological evidence bearing on the Miocene to Recent structural evolution of the New Hebrides Arc. Tectonophysics, 87:147-175.

Collot, J.-Y., Daniel, J., and Burne, R.V., 1985. Recent tectonics associated with the subduction/collision of the d'Entrecasteaux zone in the central New Hebrides. Tectonophysics, 112:325-356.

Collot, J.-Y., and Fisher, M.A., 1988. Crustal structure, from gravity data, of a collision zone in the central New Hebrides Island Arc. In Greene, H.G., and Wong, F.L. (Eds.), Geology and Offshore Resources of Pacific Island Arcs-Vanuatu Region. Circum-Pac. Counc. Energy Miner. Resour., Earth Sci. Ser., 8:125-140.

Collot, J.-Y., Greene, H.G., Stokking, L.B., et al., 1992. Proc. ODP, Init. Repts., 134: College Station, TX (Ocean Drilling Program).

Daniel, J., Gerard, M., Mauffret, A., Boulanger, D., Cantin, B., Collot, J.-Y., Durand, J., Fisher, M., Greene, H.G., Michaux, P., Pelletier B., Pezzimenti, A., Renard, V., Schaming, M., and Tissot, J.D., 1989. Déformation compressive d'un bassin intra-arc dans un contexte de collision ride-arc: le bassin d'Aoba, arc des Nouvelles-Hébrides. C. R. Acad. Sci. Ser. 2, 308:239-245.

Daniel, J., and Katz, H.R., 1981. D'Entrecasteaux zone, trench and western chain of the central New Hebrides island arc: their significance and tectonic relationship. Geo-Mar. Lett., 1:213-219.

Fisher, M.A., Falvey, D.A., and Smith, G.L., 1988. Seismic stratigraphy of the summit basins of the New Hebrides island arc. In Greene, H.G., and Wong, F.L. (Eds.), Geology and Offshore Resources of Pacific Island ArcsVanuatu Region. Circum-Pac. Counc. Energy Miner. Resour., Earth Sci. Ser., 8:201-223.

Greene, H.G., and Johnson, D.P., 1988. Geology of the central basin region of the New Hebrides arc inferred from single-channel seismic-refraction data. In Greene, H.G., and Wong, F.L. (Eds.), Geology and Offshore Resources of Pacific Island Arcs-Vanuatu Region. Circum-Pac. Counc. Energy Miner. Resour., Earth Sci. Ser., 8:117-199.

Greene, H.G., Macfarlane, A., Johnson, D.A., and Crawford, A.J., 1988. Structure and tectonics of the central New Hebrides Arc. In Greene, H.G., and Wong, F.L. (Eds.), Geology and Offshore Resources of Pacific Island Arcs-Vanuatu Region. Circum-Pac. Counc. Energy Miner. Resour., Earth Sci. Ser., 8:377-412.

Holmes, M.L., 1988. Seismic refraction measurements in the summit basins of the New Hebrides Arc. In Greene, H.G., and Wong, F.L. (Eds.), Geology and Offshore Resources of Pacific Island Arcs-Vanuatu Region. CircumPac. Counc. Energy Miner. Resour., Earth Sci. Ser., 8:163-176.

Jouannic, C., Taylor, F.W., Bloom, A.L., and Bernat, M., 1980. Late Quaternary uplift history from emerged reef terraces on Santo and Malekula Islands, central New Hebrides island arc. Tech. Bull.-U.N. Econ. Soc. Comm. Asia Pac., CCOP/SOPAC, 3:91-108.

Katz, H.R., 1981. Report on interpretation of seismic profiling data collected on the Vauban cruise in Vanuatu waters. Tech. Bull.-U. N. Econ. Soc. Comm. Asia Pac., Comm. Co-ord Jt. Prospect Miner. Resour. South Pac. Offshore Areas, 12.

, 1988. Offshore geology of Vanuatu-previous work. In Greene, H.G., and Wong, F.L. (Eds.), Geology and Offshore Resources of Pacific Island Arcs-Vanuatu Region. Circum-Pac. Counc. Energy Miner. Resour., Earth Sci. Ser., 8:93-124.

Lallemant, S.J., Byrne, T., Maltman, A., Karig, D., and Henry, P., 1993. Stress tensors at the toe of the Nankai accretionary prism: an application of inverse methods to slickenlined faults. In Hill, I.A., Taira, A., Firth, J.V., et al., Proc. ODP, Sci. Results, 131: College Station, TX (Ocean Drilling Program), 103-122.

Louat, R., and Pelletier, B., 1989. Seismotectonics and present-day relative plate motions in the New Hebrides-North Fiji basin region. Tectonophysics, 167:41-55.

Luyendyk, B.P., Bryan, W.B., and Jezek, P.A., 1974. Shallow structure of the New Hebrides island arc. Geol. Soc. Am. Bull., 85:1287-1300.

Macfarlane, A., Carney, J.N., Crawford, A.J., and Greene, H.G., 1988. Vanuatu-a review of the onshore geology. In Greene, H.G., and Wong, F.L. (Eds.), Geology and Offshore Resources of Pacific Island Arcs-Vanuatu Region. Circum-Pac. Counc. Energy Miner. Resour., Earth Sci. Ser., 8:45-91.

Mitchell, A.H.G., and Warden, A.J., 1971. Geological evolution of the New Hebrides island arc. J. Geol. Soc. London, 127:501-529.

Pontoise, B., 1984. Résultats de sismique réfraction dans la partie centrale de l'arc insulaire des Nouvelles-Hébrides. Rap. ORSTOM.

Ravenne, C., Pascal, G., Dubois, J., Dugas, F., and Montadert, L., 1977. Model of a young intra-oceanic arc: the New Hebrides island arc. In Int. Symp. 
on Geodynamics in South-west Pacific, Nouméa, New Caledonia, 1976: Paris (Editions Technip), 63-78.

Taira, A., Hill, I., Firth, J.V., et al., 1991. Proc. ODP, Init. Repts., 131: College Station, TX (Ocean Drilling Program).

Taylor, F.W., Frohlich, C., Lecolle, J., and Strecker, M., 1987. Analysis of partially emerged corals and reef terraces in the central Vanuatu Arc: comparison of contemporary coseismic and nonseismic with Quaternary vertical movements. J. Geophys. Res., 92:4905-4933.
Taylor, F.W., Isacks, B.L., Jouannic, C., Bloom, A.L., and Dubois, J., 1980. Coseismic and Quaternary vertical tectonic movements, Santo and Malekula Islands, New Hebrides island arc. J. Geophys. Res., 85:5367-5381.

Date of initial receipt: 30 April 1992

Date of acceptance: 23 September 1993

Ms 134SR-023 